\title{
ECM-integrin signalling instructs cellular position-sensing to pattern the early mouse embryo
}

Esther Jeong Yoon Kim ${ }^{1,2}$, Lydia Sorokin ${ }^{3}$, and Takashi Hiiragi ${ }^{1,4 *}$

${ }^{1}$ European Molecular Biology Laboratory (EMBL), Heidelberg, Germany

${ }^{2}$ Collaboration for joint PhD degree between EMBL and Heidelberg University,

Faculty of Biosciences, Universität Heidelberg, Heidelberg, Germany

${ }^{3}$ Institute of Physiological Chemistry and Pathobiochemistry and Cells in Motion

Interfaculty Centre (CiMIC), University of Muenster, Germany

${ }^{4}$ Institute for the Advanced Study of Human Biology (WPI-ASHBi), Kyoto University,

Kyoto, Japan

${ }^{*}$ Correspondence should be addressed to T.H. (hiiragi@embl.de). 


\section{Summary}

Development entails patterned emergence of diverse cell types within the embryo. In mammals, cells positioned inside the embryo gives rise to the inner cell mass (ICM) that eventually forms the embryo proper. Yet the molecular basis of how these cells recognise their 'inside' position to instruct their fate is unknown. Here we show that cells perceive their position through extracellular matrix (ECM) and integrin-mediated adhesion. Provision of ECM to isolated embryonic cells induces ICM specification and alters subsequent spatial arrangement between epiblast (EPI) and primitive endoderm (PrE) cells that emerge within the ICM. Notably, this effect is dependent on integrin $\beta 1$ activity and involves apical to basal conversion of cell polarity. We demonstrate that ECM-integrin activity is sufficient for 'inside' positional signalling and it is required for proper sorting of EPI/PrE cells. Our findings thus highlight the significance of ECM-integrin adhesion in enabling position-sensing by cells to achieve tissue patterning.

Key words: early mammalian development, extracellular matrix, cell fate specification, patterning 


\section{Introduction}

Development begets an immense diversity of animal forms as fertilisation is followed by organisation of cells into higher order structures. The emergence of complex patterns generally requires that cells continuously exchange signals with their surroundings to direct their fate and spatial orientation. While transcriptional networks inform individual cell type, the position at which a cell lies is critical for tissue patterning. Therefore, relay of spatial information is a ubiquitous requirement in developing systems, and a cell has to sense its position relative to its neighbours to support robust patterning. A cell may glean positional information from a variety of sources, such as mechanochemical gradients, wave-like propagation of signalling activity, as well as direct adhesive interactions with the immediate environment (Jouve et al., 2002; Steinberg and Poole, 1981; Wolpert, 1969).

In particular, adhesive interactions with the extracellular matrix (ECM) are dynamically engaged in development and homeostatic turnover of tissues (Gattazzo et al., 2014; Walma and K. M. Yamada, 2020). The ECM consists of a network of various components such as laminin, collagen IV, and fibronectin, which serve to regulate cell behaviours ranging migration, polarisation, survival, and differentiation. Its significance is evident during development, where loss of laminin chains, collagen IV, or their respective receptors leads to early embryonic lethality in mice (Miner et al., 1998; 2004; Smyth et al., 1999; Williamson et al., 1997). Furthermore, laminin regulates gene expression and spatial organisation of cells in several epithelial tissues (Klein et al., 1988; Streuli et al., 1995). In the gut, its loss leads to epithelial hyperplasia and an impaired stem cell pool, while provision of ECM through Matrigel supports long-term culture of intestinal crypt organoids (Fields et al., 2019; Sato et al., 2009). Similarly, laminin is required for proper positioning and maintenance of follicle stem cells in their niche within the Drosophila ovary (O'Reilly et al., 2008). As such, laminin as well as other ECM components have a conserved role in modulating the spatial organisation and behaviour of cells across diverse contexts.

The preimplantation mouse embryo is remarkable in its regulative capacity to preserve embryonic patterning against drastic reduction in cell number (Solter and Knowles, 1975; Tarkowski, 1959; Tarkowski and Wróblewska, 1967). This implies dynamic readout of positional information by blastomeres to adjust their fate and 
spatial arrangement in response to perturbations. By the end of the preimplantation stage at embryonic day (E) 4.5, the embryo consists of an outermost trophectoderm (TE) monolayer enclosing a fluid-filled cavity and an inner cell mass (ICM). Within the ICM, the epithelial primitive endoderm (PrE) lines the cavity while epiblast (EPI) cells reside between the PrE and the overlying TE.

Cell position instructs the first lineage segregation in mouse development, as inner and outer cells become ICM and TE, respectively (Rossant and Tam, 2009; Tarkowski and Wróblewska, 1967). Prior to TE specification, the outer surface of the embryo is marked by a polarised cortical domain enriched in phosphorylated ezrin, radixin, moesin (pERM), Par6 and atypical protein kinase C (aPKC) (Ducibella et al., 1977; Louvet et al., 1996; Vinot et al., 2005; Ziomek and Johnson, 1980). This apical domain is both necessary and sufficient for TE fate, and effectively serves as the 'outside' positional signal to prompt embryonic patterning (Alarcon, 2010; Korotkevich et al., 2017). Conversely however, insights into ICM development and its underlying 'inside' cues thus far remain sparse. Despite advances made with embryonic and induced pluripotent stem cells, there is meagre understanding of how cells with the potential to form the entire adult animal actually arise in vivo (Evans and Kaufman, 1981; Takahashi and Yamanaka, 2006). Although the ICM gives rise to the embryo proper, its study is hampered by limited accessibility and the fact that early blastomeres tend to default to a TE-like state in response to various experimental perturbations (Korotkevich et al., 2017; Lorthongpanich et al., 2012; Stephenson et al., 2010; Tarkowski and Wróblewska, 1967).

\section{Results}

\section{Inside positioning drives ICM specification during preimplantation mouse development}

The earliest marker of ICM specification is the expression of Sox2 (Guo et al., 2010; Wicklow et al., 2014). Therefore, we imaged Sox2-GFP x membrane tomato (mT) embryos with an inverted light-sheet microscope at 15-minute intervals to monitor the emergence of inside-outside cells and subsequent ICM specification (Figure 1A) (Arnold et al., 2011; Muzumdar et al., 2007; Strnad et al., 2016). This setup allowed long term live-imaging of 8-cell stage embryos until the early 
blastocyst stage with minimal phototoxicity. Given the natural embryo-to-embryo variability in developmental timing, embryonic age was standardised at the 8-to-9 cell division. Dynamic cell movements and asynchronous timing of division within each embryo led to internalisation of cells at different time points, consistent with earlier studies (Movie S1 and S2) (Dietrich and Hiiragi, 2007; Fleming, 1987). Sox2-GFP signals emerged only in completely internalised cells, and progressively increased in intensity as the embryo matured (Figure $1 \mathrm{~B}$ and $\mathrm{S} 1 \mathrm{~A}$ ).

To follow changes in Sox2 expression during ICM specification, ICM cells in the early blastocyst were retrospectively tracked to measure GFP fluorescence intensity at each time point (Figure 1C and S1B). Tracking extended to parent cells, noting the point at which each cell or its parent became internalised within the embryo. This revealed that Sox2 expression levels during ICM specification is positively correlated with early internalisation (Figure 1D). These demonstrate that inside positioning of the blastomere is crucial for ICM specification

\section{Integrin and laminin chains are localised at the cell-cell interface}

To identify the ICM-inducing cues of the embryonic intrior, we examined proteins enriched at the cell-cell interface. E-cadherin is clearly localised to cell-cell contact sites from the morula to blastocyst stages, away from TE-associated apical domains enriched in pERM (Figure $2 \mathrm{~A}$ and $2 \mathrm{~B}$ ). While E-cadherin is the major adhesive molecule that holds the cells together irrespective of their fate (Filimonow et al., 2019; Larue et al., 1994; Shirayoshi et al., 1983; Stephenson et al., 2010), several studies have shown that ECM components are also present during this period (Dziadek and Timpl, 1985; Leivo et al., 1980; Morin and Sullivan, 1994; Sutherland et al., 1993).

We found that several laminin chains are enriched at the cell-cell interface in the morula and the ICM region of the blastocyst (Figure $2 \mathrm{~A}$ and $2 \mathrm{~B}$ ). Immunostaining indicated expression of laminin 511 in addition to the already reported laminin 111, which are heterotrimers of constituent $\alpha 5, \beta 1, \gamma 1$ and $\alpha 1, \beta 1, \gamma 1$ chains, respectively (Cooper and MacQueen, 1983; Leivo et al., 1980; Miner et al., 2004; Smyth et al., 1999). Accordingly, subunits of the major laminin receptor, integrin $\alpha 6 \beta 1$, which bind both laminin 111 and 511, were similarly expressed in the preimplantation embryo (Figure 2A and 2B) (Sutherland et al., 1993; Takizawa et al., 
2017; M. Yamada and Sekiguchi, 2015). Close spatial correlation of laminin and integrin $\beta 1$ fluorescence around inner cells identified ECM-integrin interactions as candidate 'inside' positional signals to blastomeres that drive ICM specification (Figure 2C and 2D).

\section{Exogenous ECM drives ICM specification and surface integrin $\alpha 6 \beta 1$ enrichment}

To test whether the ECM provides 'inside' positional signals to drive ICM specification, we sought to mimic the inner environment of the embryo by providing the ECM through Matrigel, which is rich in laminin 111(Orkin et al., 1977; Timpl et al., 1979). Embryos were recovered at the morula stage prior to marked upregulation of Sox2, and TE-specified outer cells were removed by immunosurgery (Figure 3A). Immunosurgery not only isolates naïve inner cells, but also alters positional identity by exposing them to the external environment (Solter and Knowles, 1975).

Subsequent culture of these cells in standard embryo media (KSOM) fully restored inside-outside patterning. CDX2-positive TE cells surrounded SOX2-positive ICM cells and often a small fluid-filled cavity, reminiscent of blastocysts (Figure 3B, top panel). In this way, these isolated cells displayed robust regulative capacity.

In stark contrast, however, the TE layer was not restored in the presence of Matrigel. Instead, isolated cells formed a compact mass where the majority of nuclei were SOX2-positive, irrespective of cell position (Figure 3B). CDX2-positive cells were fewer and clustered at the periphery, while fluid-filled cavities were noticeably absent. Moreover, samples entirely composed of SOX2-positive cells were also observed across independent experiments, albeit at low frequency (9 out of 97 , $9.3 \%$ ) (Figure 3B, bottom panel). Total cell numbers were comparable between the two conditions (Figure $3 \mathrm{C}$ ), indicating that Matrigel does not have adverse effects on cell survival or proliferation.

Besides expression of $C d x 2$ and Sox2, TE and ICM cells are distinguishable by differential Hippo signalling (Nishioka et al., 2009; Wicklow et al., 2014). In inner cells, Hippo signalling results in phosphorylation and cytoplasmic retention of YAP. In outer cells, Hippo signalling is inactive, and YAP translocates to the nucleus to drive downstream transcription of $C d x 2$. Consistent with increased Sox2 expression, 
nuclear YAP localisation was diminished in Matrigel culture (Figure S2A).

Furthermore, quantitative analysis of individual nucleus for levels of each fate marker confirmed significant increase in Sox2 expression in Matrigel (Figure 3D). These findings demonstrate that exogenously supplied ECM provides 'inside' positional cues sufficient to drive ICM specification following immunosurgery.

Earlier studies noted that TE specification is preceded by ready polarisation of the outer surface after perturbations such as immunosurgery (Stephenson et al., 2010; Wigger et al., 2017). In agreement to this, pERM was enriched on the outer surface of isolated cells upon culture in KSOM, while integrin $\beta 1$ was limited to cellcell interfaces (Figure 3E, top panels). Distinct and mutually exclusive localisation of $\mathrm{pERM}$ and integrin $\beta 1$ is consistent with the apicobasal polarity that accompanies inside-outside patterning in the whole embryo. In contrast, however, Matrigel led to significant enrichment of integrin $\beta 1$ on the outer surface whereas peripheral pERM was significantly diminished (Figure $3 \mathrm{E}$, bottom panels, $3 \mathrm{G}$ and $3 \mathrm{H}$ ). Discontinuous patches of pERM were sometimes present on the surface, which generally coincided with CDX2-positive or SOX2-negative nuclei (Figure S2B). Integrin $\alpha 6$ localisation was comparable to integrin $\beta 1$ (Figure 3F), while E-cadherin was limited to cell-cell interfaces regardless of culture conditions (Figure S2C). These suggests that Matrigel, particularly its constituent laminin, brings the integrin $\alpha 6 \beta 1$ receptor to the surface in lieu of apical polarity proteins, befitting 'inside' cells.

While ICM cells are roughly isotropic in shape, TE cells are generally oblong as these are stretched around the ICM or the fluid cavity (Chan et al., 2019; Niwayama et al., 2019). However, Matrigel abrogated this difference in circularity between TE and ICM cells. The presence of round TE cells in exogenous ECM suggests that fate specification here is not dependent on cell shape (Figure 3I).

\section{Integrin $\beta 1$ activity is required for ECM-induced ICM specification}

To test whether the activity of surface enriched integrin $\alpha 6 \beta 1$ is actually required for ICM induction by Matrigel, integrin $\beta 1$ was inhibited with a functionblocking antibody, Ha2/5 (Mendrick and Kelly, 1993). Administration of Ha2/5 almost completely attenuated the effects of Matrigel. Despite the presence of exogenous ECM, outer cells polarised and became TE specified, while ICM specification was 
confined to inner cells (Figure 4A, 4B and S3A). In this way, cells cultured in Matrigel with $\mathrm{Ha} 2 / 5$ were indistinguishable from control samples. Similar observations were made upon inhibition of integrin $\alpha 6$ and assessment of YAP localisation (Figure S3B and C) (Sonnenberg et al., 1987).

Furthermore, upon genetic ablation of Itgb1, integrin $\beta 1$-deficient cells were refractory to the effects of Matrigel (Raghavan et al., 2000). Unlike cells isolated from Itgb1+/- littermate controls that exhibited increased ICM specification in Matrigel, inside-outside patterning was restored among Itgb1\% cells (Figure 4C). Therefore, 'inside' positional signals provided by the ECM require recognition through integrin activity to drive ICM specification.

\section{Integrin $\beta 1$ activity is not required for initial specification of ICM but required for EPI-PrE patterning in vivo}

Earlier observation of integrin $\beta 1$ mutant mice showed embryonic lethality post-implantation but apparently normal development through preimplantation stages (Fässler and Meyer, 1995). Accordingly, we found TE-ICM patterning and overall morphology to be comparable between wildtype (WT) and Itgb1-/- embryos during preimplantion stages (Figure 5A). However, defects were observed upon close examination of late blastocysts. Within the mature ICM, PrE cells form a epithelial monolayer that is apically polarised towards the blastocyst cavity, while EPI cells are sheltered between the PrE and the overlying TE. Although the respective numbers of EPI and PrE cells were not significantly affected by integrin $\beta 1$ deficiency, PrE cells failed to resolve into a single monolayer in Itgb1\%- embryos (Figure 5A and 5B). In addition, distribution of apical PKC $\zeta$ indicated disrupted polarity in the mutant ICM (Figure 5C and 5D), which, instead of flattening out against the TE, was more rounded in its dimensions (Figure 5E) (Saiz et al., 2013). Therefore, although integrin $\beta 1$ is not required for initial specification of the ICM in vivo, it is required for subsequent spatial organisation among EPI and PrE cells in the blastocyst. These findings reveal that defects that underlie the post-implantation lethality of Itg $101 \%$ embryos in fact arise prior to implantation. 


\section{Exogenous ECM leads to EPI cells dwelling on the surface of the ICM}

In contrast to TE-ICM specification, subsequent EPI-PrE specification is not cell position-dependent as respective cells emerge in a salt-and-pepper pattern within the ICM (Chazaud et al., 2006; Plusa et al., 2008). Nevertheless, positional information remains pertinent as EPI and PrE cells must resolve into a distinct spatial pattern as described above. Given the requirement for integrin $\beta 1$ during this latter process, we tested whether EPI and PrE cells are also receptive to exogenous ECM as positional cues.

Transcription factors NANOG and GATA6 are early markers of EPI and PrE fate, respectively. When ICMs are isolated from blastocyst at E3.5, NANOG- and GATA6-positive nuclei, as well as double-positive nuclei, are intermixed (Figure 6A and $6 \mathrm{~B})$. As such, measure of the distance between each nucleus from the centre of the ICM shows no correlation with expression of cell fate markers (Figure 6C).

Following immunosurgery and culture, the salt-and-pepper distribution of fates resolved into a pattern where polarised GATA4-positive PrE surrounded the SOX2positive EPI (Figure 6D). Positional distinction between EPI and PrE was evident based on cell fate marker expression relative to distance from the ICM centre (Figure $6 \mathrm{E})$. In stark contrast, Matrigel markedly disrupted this spatial arrangement (Figure $6 \mathrm{~F}$, top left panel). EPI cells were no longer confined to the interior, but frequently found at the surface. Quantitative analysis of fate in peripherally located cells indicated that while the vast majority of outer cells are GATA4-positive in control conditions, a significant portion expresses SOX2 in Matrigel culture (Figure 6G). Furthermore, apical polarity of the ICM surface was replaced by integrin $\beta 1$ enrichment (Figure 6F, top right panel), as observed from culture of inner cells at the earlier stage.

As with TE-ICM patterning, the effects of Matrigel on EPI-PrE patterning was dependent on integrin $\beta 1$ activity. Administration of $\mathrm{Ha} 2 / 5$ restored a peripheral polarised PrE layer in the presence of Matrigel (Figure 6F, bottom panel and 6G). These observations demonstrate that ECM-integrin adhesion provides critical positional signals to regulate EPI-PrE patterning within the ICM, consistent with its role in ICM-TE patterning. 


\section{Integrin signalling is mediated by laminin and talin}

Given our findings, we next sought to identify extracellular and intracellular components involved in ECM and integrin-mediated position-sensing.

Although laminin itself is a ligand for integrin, integrin $\beta 1$ is required for the deposition of heterotrimeric laminin, which in turn can bring its cell surface receptors together (Aumailley et al., 2000; Li et al., 2002). Accordingly, intercellular laminin, as judged by strand-like laminin $\gamma 1$ signals in the ICM, was diminished in Itgb1\%embryos (Figure 7A). Since the requirement for laminin $\gamma 1$, encoded by Lamc1, is shared by both laminin isoforms assembled during the preimplantation stage, our model also predicted integrin signalling to be impaired in Lamc1\%-embryos. In fact, PrE cells in Lamc1-/- blastocysts failed to resolve into an epithelial monolayer within the ICM (Figure 7B, bottom panels), exactly as observed in Itgb1\%-counterparts (Figure 5A). This supports our model in which intercellular laminin provides crucial positional signals that are interpreted by cells via integrin activity to instruct embryonic patterning.

Upon ECM ligand binding, the cytoplasmic domain of integrins interacts with a myriad of proteins. Among these, talin plays a key role in linking integrin to the cytoskeleton, and recruits other integrin associated proteins such as vinculin for downstream signalling (Calderwood et al., 1999; Humphries et al., 2007). Indeed, talin is localised to the cell-cell interface in the ICM alongside integrin subunits, and its expression is reduced in Itgb1-/- embryos (Figure 7A). Furthermore, where the active conformation of integrin $\beta 1$ is enriched on the surface by Matrigel culture, talin signal is also increased, both during ICM induction and in surface-positioned EPI cells (Figure 7C and 7D). Together, these strongly suggest that talin functions downstream of integrin to relay positional information from intercellular laminin to early blastomeres located inside the embryo (Figure 7E). 


\section{Discussion}

During mouse preimplantation development, ICM-TE specification follows an inside-outside pattern, while EPI and PrE cells initially emerge in an intermixed manner before becoming spatially segregated. Despite this difference, however, we show that cells maintain sensitivity to ECM-integrin signals throughout the preimplantation period to gain positional information. Given that altered patterning induced by Matrigel required integrin $\alpha 6 \beta 1$ activity, it follows that laminin, rather than other factors associated with reconstituted ECM, are pertinent for patterning the early embryo.

In developing embryos or stem cell systems where cells are yet to differentiate, a myriad of signals must be processed leading up to lineage commitment. During the first lineage segregation, Matrigel is sufficient to drive ICM specification in an integrin-dependent manner, irrespective of cell position. Yet, integrin activity is not required for inside-outside patterning per se. Given the significance of setting aside cells that will eventually form the embryo proper, other factors, such as the non-integrin laminin receptor dystroglycan, may well be active in the embryonic interior as redundant 'inside' signals (Hynes, 1987; Mui et al., 2016; Williamson et al., 1997). In addition, the ECM provided through Matrigel in our setup may be more concentrated than levels found in vivo, thereby overriding competing positional signals to drive ICM specification.

Our work complements earlier studies in embryonic stem cells that revealed ECM-integrin signals as critical regulators of the undifferentiated state and cell arrangement (Aumailley et al., 2000; Cattavarayane et al., 2015; Li et al., 2002). Given the ubiquity and tissue/stage-dependent complexity of the ECM and its receptors, their role in cell fate specification and pattern formation extends beyond early mouse development (Huang and Ingber, 2005; Humphrey et al., 2014; Walma and K. M. Yamada, 2020; Watt and Huck, 2013). Elucidation of their mechanistic contribution to patterning across diverse contexts will be instrumental to how we approach various disease states and design regenerative therapies in the future. 


\section{Materials \& Methods}

\section{Animal work}

All animal work was performed in the Laboratory Animals Resources (LAR) facility at the European Molecular Biology Laboratory (EMBL) with permission from the Institutional Animal Care and Use Committee (IACUC) overseeing the operations (IACUC \#TH110011). The LAR facility operates according to guidelines and recommendations set by the Federation for Laboratory Animal Science Associations. Mice were maintained in pathogen-free conditions under 12-hour light-dark cycles.

\section{Mouse lines}

Wildtype mice were of a $\mathrm{F} 1$ hybrid strain from $\mathrm{C} 57 \mathrm{BL} / 6$ and $\mathrm{C} 3 \mathrm{H}$ (B6C3F1) animals. The following transgenic lines were used in this study : Sox2-GFP (Arnold et al., 2011), mTmG (Muzumdar et al., 2007), Itgb1tm1Efu (floxed) (Raghavan et al., 2000), Lamc1tmStrl(floxed) (Chen and Strickland, 2003), Zp3-Cre (de Vries et al., 2000). Standard tail genotyping procedures were used to genotype transgenic mice.

To obtain Sox2-GFP x mTmG embryos, Sox2-GFP animals were crossed with $\mathrm{mTmG}$ animals. To obtain $\operatorname{ltg} 1+/-$ mice, $\operatorname{Itg} 1 \operatorname{tm} 1 E f u$ (floxed) $Z p 3-C r e^{\operatorname{tg}}$ females were crossed with B6C3F1 males. To obtain zygotic Itgb1-/- embryos, Itgb 1+/- females were crossed with Itgb1+/- males. To obtain Lamc1+/- mice, Lamc1tmStrl (floxed) Zp3$\mathrm{Cre}^{\mathrm{tg}}$ females were crossed with B6C3F1 males. To obtain zygotic Lamc1\% embryos, Lamc1+/- females were crossed with Lamc1+/- males.

\section{Superovulation and dissection of reproductive organs}

Superovulation was induced in females prior to mating to increase the number of preimplantation embryos obtained per mouse. Intraperitoneal injection of $5 \mathrm{IU}$ of PMSG (Intervet, Intergonan) and hCG (Intervet, Ovogest 1500) were carried out, with a 48-50 hour interval between the two injections. Each female mouse was put in a cage with a male immediately following hCG injection for mating.

Timing of sacrifice post-hCG injection depends on the developmental stage relevant for the experiment. Given 11AM hormone injections for superovulation, 16- 
32 cell stage embryos were recovered in the afternoon of E2.5. Early blastocysts were obtained on E3.5.

\section{Embryo work}

Preimplantation embryos were obtained by flushing the oviduct with a $1 \mathrm{ml}$ syringe filled with $\mathrm{H}-\mathrm{KSOM}$ from the infundibulum. All live embryos were handled under a stereomicroscope (Zeiss, Discovery.v8) equipped with a heating plate (Tokai hit, MATS-UST2). All live embryos were cultured in $10 \mu$ microdroplets of KSOM (potassium Simplex Optimized Medium; (Lawitts and Biggers, 1991)) with a mineral oil (Sigma, M8410) overlay inside an incubator (Thermo Fisher Scientific, Heracell $240 \mathrm{i}$ ) with a $37^{\circ} \mathrm{C}$ humidified atmosphere of $5 \% \mathrm{CO} 2$ and $95 \%$ air.

Micromanipulations outside the incubator were carried out in KSOM containing HEPES (H-KSOM; LifeGlobal, LGGH-050).

\section{Immunosurgery}

Zona pellucida were removed from embryos with 3-4 min pronase $(0.5 \% \mathrm{w} / \mathrm{v}$ Proteinase K, Sigma P8811, in H-KSOM supplemented with 0.5\% PVP-40) treatment at $37^{\circ} \mathrm{C}$ Subsequently, embryos were incubated in serum containing anti-mouse antibody (Cedarlane, CL2301, Lot no. 049M4847V) diluted 1:3 with KSOM for 30 min at $37^{\circ} \mathrm{C}$. Following three brief washes in $\mathrm{H}-\mathrm{KSOM}$, embryos were incubated in guinea pig complement (Sigma, 1639, Lot no. SLBX9353) diluted 1:3 with KSOM for $30 \mathrm{~min}$ at $37^{\circ} \mathrm{C}$. Lysed outer cells were removed by mouth-pipetting with a narrow glass capillary to isolate the inner cells.

\section{Embedding cells in Matrigel}

Matrigel mix consists of Matrigel (Corning 356230, lot. 7345012) diluted in DPBS to desired concentration $(4.5 \mathrm{mg} / \mathrm{ml})$. Matrigel mix was prepared fresh for each experiment, mixed thoroughly through pipetting, and kept on ice during immunosurgery. Upon completion of immunosurgery, isolated inner cells were promptly resuspended in the mixes, and $15 \mu \mathrm{L}$ droplets were made on $35 \mathrm{~mm}$ petri dishes (Falcon, 351008). To ensure that cell clusters from different embryos do not stick together, a closed glass capillary was used to space them apart. These petri 
dishes were inverted to prevent cells sticking to the bottom of the dish, and incubated at $37^{\circ} \mathrm{C}$ for 30 minutes for the mix to form a gel. After gel formation, $4 \mathrm{ml}$ of prewarmed KSOM was gently pipetted into each dish to cover the gel.

To inhibit integrin heterodimer activity in Matrigel-embedded cells, blocking antibodies $\mathrm{Ha} 2 / 5$ and $\mathrm{GoH} 3$ that target integrin $\beta 1$ and $\alpha 6$, respectively, were added to the overlying $\mathrm{KSOM}$ medium at a concentration of $10 \mu \mathrm{g} / \mathrm{mL}$.

\section{Immunostaining}

Embryos were fixed in 4\% PFA (Sigma, P6148) at room temperature for 15 min, washed 3 times ( 5 min each) in wash buffer (DPBS-T containing $2 \%$ BSA), permeabilised at room temperature for $30 \mathrm{~min}$ in permeabilisation buffer $(0.5 \%$ Triton-X in DPBS; Sigma T8787), washed (3 x 5 min), followed by incubation in blocking buffer (PBS-T containing 5\% BSA) either overnight at $4^{\circ} \mathrm{C}$ or for $2 \mathrm{~h}$ at room temperature. Blocked samples were incubated with primary antibodies (Table1) overnight at $4^{\circ} \mathrm{C}$, washed ( $\left.3 \times 5 \mathrm{~min}\right)$, and incubated in fluorophore-conjugated secondary antibodies and dyes (Error! Reference source not found.) for 2 hours at room temperature. Stained samples were washed ( $3 \times 5 \mathrm{~min})$, incubated in DAPI solution (Life Technologies, D3571; diluted 1:1000 in DPBS) for $10 \mathrm{~min}$ at room temperature. These samples were then transferred into droplets of DPBS overlaid with mineral oil on a 35mm glass bottom dish (MatTek, P356-1.5-20-C) for imaging.

\section{Molecular work}

\section{Single embryo genotyping}

Individual embryos were mouth pipetted into $200 \mu \mathrm{L}$ PCR tubes containing $10 \mu \mathrm{L}$ of lysis buffer consisting of $200 \mu \mathrm{g} / \mathrm{ml}$ Proteinase $\mathrm{K}$ in Taq polymerase buffer (Thermo Scientific, B38). Lysis reaction took place for 1 hour at $55^{\circ} \mathrm{C}$, followed by 10 minutes at $96^{\circ} \mathrm{C}$. Resulting genomic DNA was mixed with relevant primers (Table 3) for determination of genotype via PCR 
Table 1. Primary antibodies

\begin{tabular}{|c|c|c|c|c|}
\hline Epitope & Host & Catalogue \# & Company & Dilution \\
\hline $\mathrm{aPKC}(\mathrm{PKC} \zeta)$ & Rabbit & sc-216 & Santa Cruz Biotechnology & $1: 200$ \\
\hline CDX2 & Mouse & MU392A-UC & Biogenex & $1: 200$ \\
\hline E-cadherin & Rat & U3254 & Sigma Aldrich & $1: 100$ \\
\hline GATA4 & Goat & AF2606 & R\&D Systems & $1: 200$ \\
\hline GATA6 & Goat & AF1700 & R\&D Systems & $1: 200$ \\
\hline $\begin{array}{l}\text { Integrin } \alpha 6 \\
(\mathrm{GoH} 3)\end{array}$ & Rat & 555734 & BD Pharmingen & $1: 100$ \\
\hline Integrin $\beta 1$ & Rat & MAB1997 & Millipore & $1: 100$ \\
\hline $\begin{array}{l}\text { Integrin } \beta 1 \\
(\mathrm{Ha} 2 / 5)\end{array}$ & Rat & 555002 & BD Pharmingen & $1: 100$ \\
\hline $\begin{array}{l}\text { Laminin (non- } \\
\text { chain specific) }\end{array}$ & Rabbit & NB300-14422 & Novus Biologicals & $1: 100$ \\
\hline Laminin $\alpha 5$ & Rat & $\mathrm{n} / \mathrm{a}$ & Gift from Lydia Sorokin & $\mathrm{N} / \mathrm{A}$ \\
\hline Laminin $\beta 1$ & Rat & $\mathrm{n} / \mathrm{a}$ & Gift from Lydia Sorokin & $\mathrm{N} / \mathrm{A}$ \\
\hline Laminin $\gamma 1$ & Rat & $\mathrm{n} / \mathrm{a}$ & Gift from Lydia Sorokin & $\mathrm{N} / \mathrm{A}$ \\
\hline NANOG & Rabbit & RCAB002P-F & ReproCELL, Inc & $1: 200$ \\
\hline YAP1 & Mouse & $\begin{array}{l}\text { H00010413- } \\
\text { M01 }\end{array}$ & Abnova & $1: 100$ \\
\hline Phospho-ERM & Rabbit & 3726 & Cell Signaling Technology & $1: 200$ \\
\hline Sox-2 (D9B8N) & Rabbit & 23064 & Cell Signaling Technology & $1: 200$ \\
\hline
\end{tabular}

Table 2. Secondary antibodies and dyes

\begin{tabular}{|l|l|l|l|l|l|}
\hline Fluorophore & Target & Host & Catalogue \# & Company & Dilution \\
\hline Alexa Fluor 488 & Goat IgG & Donkey & A11055 & Life Technologies & $1: 200$ \\
\hline Alexa Fluor 488 Plus & Rabbit IgG & Donkey & A32790 & ThermoFisher & $1: 200$ \\
\hline Alexa Fluor 546 & Rabbit IgG & Donkey & A10040 & ThermoFisher & \\
\hline Cy5 & Mouse IgG & Donkey & $715-175-150$ & $\begin{array}{l}\text { Jackson } \\
\text { ImmunoResearch }\end{array}$ & $1: 200$ \\
\hline Cy5 & Rat IgG & Donkey & $712-175-153$ & $\begin{array}{l}\text { Jackson } \\
\text { ImmunoResearch }\end{array}$ & $1: 200$ \\
\hline DAPI & (DNA) & - & D3571 & Life Technologies & $1: 1000$ \\
\hline Rhodamine phalloidin & (Actin) & - & R415 & Invitrogen & $1: 200$ \\
\hline
\end{tabular}


Table 3. Sequence of genotyping primers

\begin{tabular}{|l|l|l|l|}
\hline $\begin{array}{l}\text { Mouse } \\
\text { line/locus }\end{array}$ & Primer 1 & Primer 2 & Primer 3 \\
\hline Itgb1 deleted & $\begin{array}{l}\text { TGAATATGGGCTTGG } \\
\text { CAGTTA }\end{array}$ & $\begin{array}{l}\text { CCACAACTTTCCCA } \\
\text { GTTAGCTCTC }\end{array}$ & \\
\hline Itgb1 tm1 Efu & $\begin{array}{l}\text { CGGCTCAAAGCAGA } \\
\text { GTGTCAGTC }\end{array}$ & $\begin{array}{l}\text { CCACAACTTTCCCA } \\
\text { GTTAGCTCTC }\end{array}$ & \\
\hline Lamc1 deleted/ 1 tmStrl & $\begin{array}{l}\text { AAA GAA GCA GAG } \\
\text { TGT GGG GG }\end{array}$ & $\begin{array}{l}\text { TGG CCT TTT CAA } \\
\text { CCC TGG AA }\end{array}$ & $\begin{array}{l}\text { GCC TTC TAT CGC } \\
\text { CTT CTT GAC }\end{array}$ \\
\hline mTmG & $\begin{array}{l}\text { CTCTGCTGCCTCCTG } \\
\text { GCTTCT }\end{array}$ & $\begin{array}{l}\text { CGAGGCGGATCAC } \\
\text { AAGCAATA }\end{array}$ & $\begin{array}{l}\text { TCAATGGGCGGGG } \\
\text { GTCGTT }\end{array}$ \\
\hline ZP3 Cre & $\begin{array}{l}\text { TGCTGTTTCACTGGT } \\
\text { TGTGCGGCG }\end{array}$ & $\begin{array}{l}\text { TGCCTTCTCTACAC } \\
\text { CTGCGGTGCT }\end{array}$ & \\
\hline Sox2-GFP & $\begin{array}{l}\text { CTC GAG ATC CAC } \\
\text { TAG TTC TAG CC }\end{array}$ & $\begin{array}{l}\text { TCT CGG TCT TTT } \\
\text { CAT TTC AGG }\end{array}$ & $\begin{array}{l}\text { CCG TCA TTT GGG } \\
\text { TCT TTA TTC }\end{array}$ \\
\hline
\end{tabular}

\section{Microscopy and image analyses}

Fixed and stained embryos were imaged on the Zeiss LSM780 and LSM880 confocal microscopes. For both systems, a 40X water-immersion C-Apochromat 1.2 NA objective lens was used. Imaging was carried out with the Zen (Zeiss) software interface. Resulting raw images were processed using ImageJ. Further quantification of fluorescence intensities and nuclei/cell counting was performed on either Image J or Imaris 9.2.1 (Oxford Instruments) as described below.

\section{Light-sheet live-imaging}

Sox2-GFP x mT embryos were live-imaged using InVi SPIM (Strnad et al., 2016). Embryos were mounted on a V-shaped sample holder covered with transparent FEP foil. Each embryo was placed in a small microwell made by gently pressing a closed glass pipette into the foil. Embryos were immersed in $100 \mu \mathrm{L}$ KSOM medium and covered in $150 \mu \mathrm{L}$ mineral oil to prevent evaporation. The samples were imaged inside an environmentally controlled incubation chamber with $5 \% \mathrm{CO}_{2}$ and $5 \% \mathrm{O}_{2}$ at $37{ }^{\circ} \mathrm{C}$. 
InVi SPIM was equipped with a Nikon 25x/1.1NA water immersion detective objective and a Nikon 10x/0.3 NA water immersion illumination objective. Illumination plane and focal plane were aligned before each imaging session. Images were taken every 15 minutes from the 8-cell stage to the early blastocyst stage by a CMOS camera (Hamamatsu, ORCA Flash4.0 V2) with line-scan mode.

\section{Quantification of Sox2-GFP fluorescence intensity during ICM specification}

GFP fluorescence intensity was measured at each time point by drawing a region of interest $(\mathrm{ROI})$ within the cross-section of each ICM cell and obtaining the mean grey value on ImageJ. Each ICM cell was identified in the blastocyst based on GFP fluorescence and retrospectively tracked to identify the point of internalisation. A cell was considered to be 'internalised' when its entire surface was surrounded by adjacent cells, with no area exposed to the external environment. Tracking extended to parent cells prior to Sox2 upregulation. For each embryo, 8-11 ICM cells were tracked in this way.

Background fluorescence was quantified by calculating the average intensity in blastomeres during the 8-cell, morula, and blastocyst stages. This value was subtracted from measured Sox2-GFP intensity of ICM cells.

\section{Measure of cell circularity}

Circularity measurement were obtained by tracing the outline of individual cells on ImageJ. From each cluster, up to 4-8 TE- and ICM-specified cells were traced across their mid-section. Cells undergoing division were not included, as cells round up during mitosis.

\section{Measure of ICM width and length in blastocysts}

A confocal image slice was taken through the mid-section of the ICM. Width was defined as the distance between the centre of the PrE layer and the ICM-TE boundary. Length was defined as the distance between two PrE cells at the opposite ends. A straight line was drawn for width and length, and the distance was measured in ImageJ. 


\section{Quantification of fluorescence intensity of lineage markers}

For measure of lineage specification, Imaris was used. Imaris Surpass allowed 3D visualisation of the image data. The 'Add Spots' function was used to detect each nucleus on the DAPI channel. Estimated spot (nucleus) diameter was set to $6 \mu \mathrm{m}$, and manual corrections were made for each image as necessary to detect all nuclei. Mean fluorescence intensity of SOX2, CDX2 or GATA4 were measured for each detected nucleus. Spot detection of each nucleus was also used as a cell counter.

\section{Quantification of fluorescence intensity of apicobasal markers}

Fluorescence signal intensity of cortical pERM and integrin $\beta 1$ was used as a measure of apical and basal polarity, respectively. Images of samples stained for these proteins were analysed on ImageJ. To reduce noise, the Gaussian filter was applied to smooth the image. For each z-stack, a mid-slice was selected, and a line was traced along the perimeter of the smoothed image. A plot profile along the line was obtained for the $\mathrm{pERM}$ and integrin $\beta 1$ channels. Individual data points were exported from ImageJ for statistical analysis.

\section{Statistical analysis}

Statistical analyses and graph generation was performed using the ggplot2 package in $\mathrm{R}$ and Microsoft Excel. Comparison of the distribution of fate marker intensities was performed by the Mann-Whitney $U$ test. Differences in cell count, surface enrichment of apicobasal polarity markers, circularity, and ICM dimensions were assessed using the student's $t$-test (two-sided). Statistical dependence between Sox2-GFP intensity and duration a cell resides in the embryonic interior, and relationship between EPI/PrE fate marker expression and cell position were assessed by Pearson's correlation. 


\section{Acknowledgements}

We are grateful to members of the Hiiragi Group and Aissam Ikmi for critical comments and suggestions. Karen-Sue Carlson kindly provided Lamc1 fl/fl mice. We also thank Ramona Bloehs, Stefanie Friese, Lidia Perez, and the Laboratory Animal Resources at EMBL for technical support with mouse work. E.J.Y.K. is supported by the EMBL International PhD Programme, and the Hiiragi Group is supported by EMBL and the European Research Council (ERC Advanced Grant "Self-organising Embryo", grant agreement 742732).

\section{Author contributions}

The project was conceived and designed by E.J.Y.K and T.H. L.S. provided expertise and reagents relating to the ECM, particularly laminin, which further guided the design of the project. E.J.Y.K. carried out all experiments, including mouse experiments, imaging and data analysis under the supervision of T.H. E.J.Y.K. wrote the manuscript, which was reviewed and edited by L.S. and T.H. for the final version. T.H. acquired the funding.

\section{Competing interests}

The authors declare no competing interests. 


\section{Figure legends}

Figure 1. ICM fate specification is induced by inner positioning of the blastomere.

(A) Schematic representation of live-imaging setup for preimplantation mouse development using selective plane illumination microscopy (SPIM). Fluorescent embryos expressing Sox2-GFP and membrane tomato $(\mathrm{mT})$ were imaged from the 8cell stage until the early blastocyst stage at 15 -minute intervals. For subsequent image analysis, time $(\mathrm{t})=0$ was set at the 8-to-9 cell division.

(B) Time-lapse images of ICM specification during preimplantation development of a representative Sox2-GFP x mT embryo. Time, post 8-to-9 cell division (h:min). Scale bar $=20 \mu \mathrm{m}$.

(C) Changes in Sox2-GFP intensity in inner cells during ICM specification. Cells become internalised at different timepoints (vertical dashed lines). Each line represents a single cell that becomes ICM-specified, and sister cells are marked in the same colour. Plot shows retrospectively tracked fluorescence intensities of $10 \mathrm{ICM}$ cells from a representative embryo.

(D) Scatterplot of normalised Sox2-GFP intensity and duration a cell resides in the embryonic interior completely surrounded by neighbouring cells. For each embryo, Sox2-GFP intensity was normalised to mean levels measured in the blastocyst. Pearson's correlation was calculated at $\mathrm{t}=15 \mathrm{~h}$ when heterogeneity in Sox2 expression becomes apparent across different embryos. $N=4$ embryos, $n=40$ cells. See also Figure S1.

Figure 2. Integrin and laminin are expressed in the morula and colocalise in the blastocyst. (A and B) Localisation of E-cadherin, laminin chains $\alpha 5$ and $\gamma 1$, and integrin $\alpha 6$ and $\beta 1$ subunits in morulae (A) and blastocysts (B). Phosphorylated ezrin, radixin, moesin ( $p E R M)$ marks the cell-free apical surface of outer cells.

(C) Co-immunostaining for integrin $\beta 1$ and laminin (non-chain-specific) in the blastocyst marks their shared localisation at the cell-cell interface. Scale bars $=20 \mu \mathrm{m}$.

(D) Representative intensity profile of integrin $\beta 1$ and laminin around an inner cell (marked by dashed white line in (C), arrowhead indicates starting point of measurement). 


\section{Figure 3. Exogenous ECM drives ICM specification and surface integrin $\alpha 6 \beta 1$}

enrichment. (A) Schematic representation of experimental conditions and immunosurgery. Morula stage embryos are recovered prior to ICM specification, and lysis of outer cells leaves behind isolated inner cells. Immediately following immunosurgery, inner cells are cultured in either standard KSOM mouse embryo media or Matrigel before assessment of patterning.

(B) Representative images of TE-ICM fate specification following immunosurgery and culture in either control KSOM or Matrigel. CDX2 marks TE fate while SOX2 marks ICM fate. In a few cases, Matrigel culture induces SOX2 upregulation across the entire cell cluster (bottom panel). Scale bars $=20 \mu \mathrm{m}$.

(C) Total cell count after immunosurgery and culture in either KSOM (purple) or Matrigel (green). Each data point represents inner cells cultured from a single embryo.

Student's $t$-test, two-sided. Error bars show mean \pm s.d. $N=43$ embryos.

(D) Scatterplot and adjacent violin plots show normalised fluorescence intensities of CDX2 and SOX2 measured for each cell cultured in either KSOM (purple) or Matrigel (green).

Mann-Whitney $U$ test. $N=43$ embryos ( $n=912$ cells).

( $E$ and $F$ ) Representative images of pERM (apical marker), integrin $\beta 1$, and integrin $\alpha 6$ localisation in cultured inner cells.

( $G$ and $H$ ) Quantification of surface enrichment of integrin $\beta 1$ and pERM fluorescence.

Student's $t$-test, two-sided. Error bars show mean \pm s.d. $N=49(F)$ and $N=38(G)$ embryos.

(I) Circularity as a descriptor of cell shape measured for individual TE- and ICMspecified cells across the two culture conditions. Student's $t$-test, two-sided. Error bars show mean \pm s.d. $N=46$ embryos ( $n=288$ cells). See also Figure S2.

Figure 4. ICM induction by Matrigel is dependent on integrin $\beta 1$ activity.

(A) Schematic representation of experimental conditions and representative images of TE-ICM patterning upon administration of integrin $\beta 1$ function-blocking antibody, $\mathrm{Ha2} / 5$ $(10 \mu \mathrm{g} / \mathrm{ml})$ with Matrigel.

(B) Scatterplot and adjacent violin plots show normalised fluorescence intensities of CDX2 and SOX2 measured for each cell cultured in either KSOM (purple), Matrigel only (light green) or Matrigel with Ha2/5 (orange). Mann-Whitney $U$ test. Plot represents 
data combined from $\mathrm{N}=93$ embryos ( $\mathrm{n}=1332$ cells). Data for KSOM and Matrigel are duplicated from Figure 3D for ease of comparision.

(C) Schematic representation of experimental conditions and representative images of inner cells isolated from Itgb1 transgenic embryos cultured in either KSOM or Matrigel. Each sample is genotyped retrospectively to identify Itgb1-/- samples. $\mathrm{N}=25$ embryos $\left(14 \mathrm{ltg} b 1^{+/-}\right.$and $\left.11 \mathrm{ltg} b 1^{-/-}\right)$. Scale bars $=20 \mu \mathrm{m}$. See also Figure S3.

\section{Figure 5. EPI-PrE patterning in the late blastocyst in vivo requires integrin $\beta 1$.}

(A) Representative images of patterning in preimplantation stage WT and Itgb1-/embryos through morula, early and late blastocyst stages.

(B) Cell count of GATA4-expressing PrE cells and SOX2-expressing EPI cells within the ICM of WT and Itgb1-/- late blastocysts. Student's $t$-test, two-sided. Error bars show mean \pm s.d. $\mathrm{N}=31$ embryos (11 WT, 20 Itgb1//-).

(C) Representative image of EPI-PrE arrangement and apical polarity of the ICM of WT and Itg 1 1/- late blastocysts. OCT4(red) marks EPI, GATA4 (green) marks PrE, and $\mathrm{PKC \zeta (grey)} \mathrm{marks} \mathrm{apical} \mathrm{polarity.}$

(D) Representative intensity profile of PKC $\zeta$ across the ICM of WT and Itgb1/- late blastocysts along the red line of interest marked in (C).

(E) Width and length of the ICM in WT and Itgb1-/- late blastocysts. Student's $t$-test, two-sided. Error bars show mean \pm s.d. $\mathrm{N}=39$ embryos (14 WT, 25 Itgb1-/-).

Figure 6. EPI-PrE patterning is sensitive to Matrigel and integrin $\beta 1$ activity.

(A) Schematic representation of experimental conditions with immunosurgery of blastocysts. Blastocysts are subjected to immunosurgery to isolate salt-and-pepper stage ICMs. Isolated ICMs are cultured in either KSOM or Matrigel before assessment of patterning.

(B) Representative image of an isolated salt-and-pepper ICM expressing early EPI marker NANOG and early PrE marker GATA6.

(C) Scatterplots showing fluorescence intensities of NANOG and GATA6 in relation to cell position within an isolated ICM. Position is measured as distance between each nucleus and the centre of the ICM. Pearson's correlation. ICMs from $N=28$ embryos ( $n$ $=658$ cells $)$.

(D) Representative images of EPI-PrE arrangement and apicobasal polarity of ICMs following culture in KSOM. 
(E) Scatterplots showing fluorescence intensities of SOX2 and GATA4 in relation to cell position following culture of ICMs in KSOM. Pearson's correlation. ICMs from N = 35 embryos ( $n=765$ cells).

(F) Representative images of EPI-PrE spatial arrangement and apicobasal polarity of ICMs following culture in Matrigel or Matrigel with integrin $\beta 1$ function-blocking antibody, $\mathrm{Ha} 2 / 5(10 \mu \mathrm{g} / \mathrm{ml})$. Scale bars $=20 \mu \mathrm{m}$.

(G) Scatterplot and adjacent violin plots show normalised fluorescence intensities of GATA4 and SOX2 measured for each cell cultured in KSOM (purple), Matrigel (green), or Matrigel with Ha2/5 (orange). Mann-Whitney U test. Plot represents data from ICMs from $N=59$ embryos ( $n=1664$ cells). ${ }^{* *} p<0.0001$

\section{Figure 7. Integrin signalling is mediated by laminin and talin during early}

embryonic patterning. (A) Representative images of talin and laminin $\gamma 1$ chain expression in whole blastocysts of $\operatorname{tg} 61+/$ - or Itgb1-/- genotype. Itgb1+/- embryos serve as littermate controls.

(B) Representative images of EPI-PrE patterning within the ICM of WT and Lamc1-/- late blastocysts.

(C and D) Representative images of localisation of talin and the active conformation of integrin $\beta 1$, following immunosurgery at either E2.5 (C) or E3.5 (D) and culture in KSOM or Matrigel. Scale bars $=20 \mu \mathrm{m}$.

(E) Schematic outline of laminin-integrin dependent position-sensing by inner cells of the preimplantation mouse embryo. This mechanism for recognition of 'inside' position by the cells is shared between morula and blastocyst stage embryos, and modulates cell fate specification as well as spatial arrangement among cells.

Figure S1. ICM fate specification is induced by inner positioning of blastomeres.

Related to Figure 1. (A) Time-lapse images of ICM specification during preimplantation development of a Sox2-GFP x mT embryo. Time, post 8-to-9 cell division (h:min).

Scale bar $=20 \mu \mathrm{m}$.

(B) Changes in Sox2-GFP intensity during ICM specification in different embryos. For each blastocyst, 8-11 SOX2-positive cells were retrospectively tracked and GFP intensities were measured. Cells become internalised at different timepoints (vertical dashed lines). Each line represents a single cell that becomes ICM-specified, and sister cells are marked in the same colour. 
Figure S2. Exogenous ECM drives Hippo signalling and suppresses apical polarity. Related to Figure 3. (A) Representative images of TE-ICM fate specification in inner cells following immunosurgery and culture in KSOM or Matrigel. SOX2 marks ICM fate while nuclear YAP1 is characteristic of TE cells.

(B) Partial enrichment of pERM on the surface of isolated cells cultured in Matrigel. The cell with the patch of pERM signal $\left(^{*}\right)$ is SOX2-negative.

(C) Representative images of E-cadherin localisation in isolated cells following culture in KSOM or Matrigel. Scale bar $=20 \mu \mathrm{m}$.

Figure S3. Integrin $\alpha 6 \beta 1$ inhibition restores inside-outside patterning to Matrigelcultured cells. Related to Figure 4. (A) Representative images of apicobasal polarity in cells cultured in Matrigel with integrin $\beta 1$ function-blocking antibody Ha2/5 (10 $\mu \mathrm{g} / \mathrm{ml})$. Phosphorylated ERM (pERM) proteins mark apical domain.

(B) Representative images of TE-ICM fate specification following culture in KSOM, Matrigel, or Matrigel with integrin $\alpha 6$ function-blocking antibody GoH3 (10 $\mu \mathrm{g} / \mathrm{ml})$. (C) Representative images of inside-outside patterning following culture in Matrigel with either Ha2/5 or GoH3. In addition to SOX2 expression, differential localisation of YAP1 distinguishes TE and ICM fate, as YAP1 is nuclear localised in TE cells.

Movie S1 and S2. Time-lapse videos of ICM specification during preimplantation development of a representative Sox2-GFP x mT embryos. Movie S1 corresponds to Figure 1B. Movie S2 corresponds to Figure S1A. Time, post 8-to-9 cell division (h:min). 


\section{References}

Alarcon, V.B., 2010. Cell Polarity Regulator PARD6B Is Essential for Trophectoderm Formation in the Preimplantation Mouse Embryo1. Biology of Reproduction 83, 347358. doi:10.1095/biolreprod.110.084400

Arnold, K., Sarkar, A., Yram, M.A., Polo, J.M., Bronson, R., Sengupta, S., Seandel, M., Geijsen, N., Hochedlinger, K., 2011. Sox2(+) adult stem and progenitor cells are important for tissue regeneration and survival of mice. Cell Stem Cell 9, 317-329. doi:10.1016/j.stem.2011.09.001

Aumailley, M., Pesch, M., Tunggal, L., Gaill, F., Fässler, R., 2000. Altered synthesis of laminin 1 and absence of basement membrane component deposition in (beta) 1 integrin-deficient embryoid bodies. J Cell Sci 113 Pt 2, 259-268.

Calderwood, D.A., Zent, R., Grant, R., Rees, D.J., Hynes, R.O., Ginsberg, M.H., 1999. The Talin head domain binds to integrin beta subunit cytoplasmic tails and regulates integrin activation. J. Biol. Chem. 274, 28071-28074. doi:10.1074/jbc.274.40.28071

Cattavarayane, S., Palovuori, R., Tanjore Ramanathan, J., Manninen, A., 2015. a6ß1and $\alpha \mathrm{V}$-integrins are required for long-term self-renewal of murine embryonic stem cells in the absence of LIF. BMC Cell Biol. 16, 3. doi:10.1186/s12860-015-0051-y Chan, C.J., Costanzo, M., Ruiz-Herrero, T., Mönke, G., Petrie, R.J., Bergert, M., DizMuñoz, A., Mahadevan, L., Hiiragi, T., 2019. Hydraulic control of mammalian embryo size and cell fate. Nature 571, 112-116. doi:10.1038/s41586-019-1309-x

Chazaud, C., Yamanaka, Y., Pawson, T., Rossant, J., 2006. Early lineage segregation between epiblast and primitive endoderm in mouse blastocysts through the Grb2MAPK pathway. DEVCEL 10, 615-624. doi:10.1016/j.devcel.2006.02.020

Chen, Z.-L., Strickland, S., 2003. Laminin gamma1 is critical for Schwann cell differentiation, axon myelination, and regeneration in the peripheral nerve. $\mathrm{J}$ Cell Biol 163, 889-899. doi:10.1083/jcb.200307068

Cooper, A.R., MacQueen, H.A., 1983. Subunits of laminin are differentially synthesized in mouse eggs and early embryos. Developmental Biology 96, 467-471. doi:10.1016/0012-1606(83)90183-5

de Vries, W.N., Binns, L.T., Fancher, K.S., Dean, J., Moore, R., Kemler, R., Knowles, B.B., 2000. Expression of Cre recombinase in mouse oocytes: A means to study maternal effect genes. Genesis 26, 110-112. doi:10.1002/(SICI)1526-

968X(200002)26:2<110::AID-GENE2>3.0.CO;2-8 
Dietrich, J.-E., Hiiragi, T., 2007. Stochastic patterning in the mouse pre-implantation embryo. Development 134, 4219-4231. doi:10.1242/dev.003798

Ducibella, T., Ukena, T., Karnovsky, M., Anderson, E., 1977. Changes in cell surface and cortical cytoplasmic organization during early embryogenesis in the preimplantation mouse embryo. J Cell Biol 74, 153-167. doi:10.1083/jcb.74.1.153

Dziadek, M., Timpl, R., 1985. Expression of nidogen and laminin in basement membranes during mouse embryogenesis and in teratocarcinoma cells. Developmental Biology 111, 372-382. doi:10.1016/0012-1606(85)90491-9

Evans, M.J., Kaufman, M.H., 1981. Establishment in culture of pluripotential cells from mouse embryos. Nature 292, 154-156. doi:10.1038/292154a0

Fässler, R., Meyer, M., 1995. Consequences of lack of beta 1 integrin gene expression in mice. Genes \& Development 9, 1896-1908. doi:10.1101/gad.9.15.1896

Fields, B., DeLaForest, A., Zogg, M., May, J., Hagen, C., Komnick, K., Wieser, J., Lundberg, A., Weiler, H., Battle, M.A., Carlson, K.-S., 2019. The Adult Murine Intestine is Dependent on Constitutive Laminin- $\gamma 1$ Synthesis. Nature Publishing Group 9, 19303.

Filimonow, K., Saiz, N., Suwińska, A., Wyszomirski, T., Grabarek, J.B., Ferretti, E., Piliszek, A., Plusa, B., Maleszewski, M., 2019. No evidence of involvement of Ecadherin in cell fate specification or the segregation of Epi and PrE in mouse blastocysts. PLoS ONE 14, e0212109. doi:10.1371/journal.pone.0212109

Fleming, T.P., 1987. A quantitative analysis of cell allocation to trophectoderm and inner cell mass in the mouse blastocyst. Developmental Biology 119, 520-531. doi:10.1016/0012-1606(87)90055-8

Gattazzo, F., Urciuolo, A., Bonaldo, P., 2014. Extracellular matrix: a dynamic microenvironment for stem cell niche. Biochimica et Biophysica Acta 1840, 25062519. doi:10.1016/j.bbagen.2014.01.010

Guo, G., Huss, M., Tong, G.Q., Wang, C., Li Sun, L., Clarke, N.D., Robson, P., 2010. Resolution of cell fate decisions revealed by single-cell gene expression analysis from zygote to blastocyst. Developmental Cell 18, 675-685.

doi:10.1016/j.devcel.2010.02.012

Huang, S., Ingber, D.E., 2005. Cell tension, matrix mechanics, and cancer development.

Cancer Cell 8, 175-176. doi:10.1016/j.ccr.2005.08.009

Humphrey, J.D., Dufresne, E.R., Schwartz, M.A., 2014. Mechanotransduction and extracellular matrix homeostasis. Nature Reviews Molecular Cell Biology 15, 802812. doi:10.1038/nrm3896 
Humphries, J.D., Wang, P., Streuli, C., Geiger, B., Humphries, M.J., Ballestrem, C., 2007. Vinculin controls focal adhesion formation by direct interactions with talin and actin. J Cell Biol 179, 1043-1057. doi:10.1083/jcb.200703036

Hynes, R.O., 1987. Integrins: a family of cell surface receptors. Cell 48, 549-554. doi:10.1016/0092-8674(87)90233-9

Jouve, C., limura, T., Pourquié, O., 2002. Onset of the segmentation clock in the chick embryo: evidence for oscillations in the somite precursors in the primitive streak. Development 129, 1107-1117.

Klein, G., Langegger, M., Timpl, R., Ekblom, P., 1988. Role of laminin A chain in the development of epithelial cell polarity. Cell 55, 331-341. doi:10.1016/00928674(88)90056-6

Korotkevich, E., Niwayama, R., Courtois, A., Friese, S., Berger, N., Buchholz, F., Hiiragi, T., 2017. The Apical Domain Is Required and Sufficient for the First Lineage Segregation in the Mouse Embryo. DEVCEL 40, 235-247.e7. doi:10.1016/j.devcel.2017.01.006

Larue, L., Ohsugi, M., Hirchenhain, J., Kemler, R., 1994. E-cadherin null mutant embryos fail to form a trophectoderm epithelium. Proceedings of the National Academy of Sciences 91, 8263-8267. doi:10.1073/pnas.91.17.8263

Lawitts, J.A., Biggers, J.D., 1991. Optimization of mouse embryo culture media using simplex methods. J. Reprod. Fertil. 91, 543-556. doi:10.1530/jrf.0.0910543

Leivo, I., Vaheri, A., Timpl, R., Wartiovaara, J., 1980. Appearance and distribution of collagens and laminin in the early mouse embryo. Developmental Biology 76, 100114. doi:10.1016/0012-1606(80)90365-6

Li, S., Harrison, D., Carbonetto, S., Fässler, R., Smyth, N., Edgar, D., Yurchenco, P.D., 2002. Matrix assembly, regulation, and survival functions of laminin and its receptors in embryonic stem cell differentiation. J Cell Biol 157, 1279-1290. doi:10.1083/jcb.200203073

Lorthongpanich, C., Doris, T.P.Y., Limviphuvadh, V., Knowles, B.B., Solter, D., 2012. Developmental fate and lineage commitment of singled mouse blastomeres. Development 139, 3722-3731. doi:10.1242/dev.086454

Louvet, S., Aghion, J., Santa-Maria, A., Mangeat, P., Maro, B., 1996. Ezrin becomes restricted to outer cells following asymmetrical division in the preimplantation mouse embryo. Developmental Biology 177, 568-579. doi:10.1006/dbio.1996.0186 Mendrick, D.L., Kelly, D.M., 1993. Temporal expression of VLA-2 and modulation of its ligand specificity by rat glomerular epithelial cells in vitro. Lab Invest 69, 690-702. 
Miner, J.H., Cunningham, J., Sanes, J.R., 1998. Roles for laminin in embryogenesis: exencephaly, syndactyly, and placentopathy in mice lacking the laminin alpha5 chain. J Cell Biol 143, 1713-1723. doi:10.1083/jcb.143.6.1713

Miner, J.H., Li, C., Mudd, J.L., Go, G., Sutherland, A.E., 2004. Compositional and structural requirements for laminin and basement membranes during mouse embryo implantation and gastrulation. Development 131, 2247-2256. doi:10.1242/dev.01112

Morin, N., Sullivan, R., 1994. Expression of fibronectin and a fibronectin-binding molecule during preimplantation development in the mouse. Hum Reprod 9, 894901. doi:10.1093/oxfordjournals.humrep.a138613

Mui, K.L., Chen, C.S., Assoian, R.K., 2016. The mechanical regulation of integrincadherin crosstalk organizes cells, signaling and forces. J Cell Sci 129, 1093-1100. doi:10.1242/jcs.183699

Muzumdar, M.D., Tasic, B., Miyamichi, K., Li, L., Luo, L., 2007. A global doublefluorescent Cre reporter mouse. Genesis 45, 593-605. doi:10.1002/dvg.20335

Nishioka, N., Inoue, K.-I., Adachi, K., Kiyonari, H., Ota, M., Ralston, A., Yabuta, N., Hirahara, S., Stephenson, R.O., Ogonuki, N., Makita, R., Kurihara, H., MorinKensicki, E.M., Nojima, H., Rossant, J., Nakao, K., Niwa, H., Sasaki, H., 2009. The Hippo signaling pathway components Lats and Yap pattern Tead4 activity to distinguish mouse trophectoderm from inner cell mass. Developmental Cell 16, 398410. doi:10.1016/j.devcel.2009.02.003

Niwayama, R., Moghe, P., Liu, Y.-J., Fabrèges, D., Buchholz, F., Piel, M., Hiiragi, T., 2019. A Tug-of-War between Cell Shape and Polarity Controls Division Orientation to Ensure Robust Patterning in the Mouse Blastocyst. Developmental Cell 51, 564574.e6. doi:10.1016/j.devcel.2019.10.012

O'Reilly, A.M., Lee, H.-H., Simon, M.A., 2008. Integrins control the positioning and proliferation of follicle stem cells in the Drosophila ovary. J Cell Biol 182, 801-815. doi:10.1083/jcb.200710141

Orkin, R.W., Gehron, P., McGoodwin, E.B., Martin, G.R., Valentine, T., Swarm, R., 1977. A murine tumor producing a matrix of basement membrane. The Journal of Experimental Medicine 145, 204-220.

Plusa, B., Piliszek, A., Frankenberg, S., Artus, J., Hadjantonakis, A.-K., 2008. Distinct sequential cell behaviours direct primitive endoderm formation in the mouse blastocyst. Development 135, 3081-3091. doi:10.1242/dev.021519

Raghavan, S., Bauer, C., Mundschau, G., Li, Q., Fuchs, E., 2000. Conditional ablation of beta1 integrin in skin. Severe defects in epidermal proliferation, basement 
membrane formation, and hair follicle invagination. J Cell Biol 150, 1149-1160. doi:10.1083/jcb.150.5.1149

Rossant, J., Tam, P.P.L., 2009. Blastocyst lineage formation, early embryonic

asymmetries and axis patterning in the mouse. Development 136, 701-713. doi:10.1242/dev.017178

Saiz, N., Grabarek, J.B., Sabherwal, N., Papalopulu, N., Plusa, B., 2013. Atypical protein kinase $\mathrm{C}$ couples cell sorting with primitive endoderm maturation in the mouse blastocyst. Development 140, 4311-4322. doi:10.1242/dev.093922

Sato, T., Vries, R.G., Snippert, H.J., van de Wetering, M., Barker, N., Stange, D.E., van Es, J.H., Abo, A., Kujala, P., Peters, P.J., Clevers, H., 2009. Single Lgr5 stem cells build crypt-villus structures in vitro without a mesenchymal niche. Nature 459, 262265.

Shirayoshi, Y., Okada, T.S., Takeichi, M., 1983. The calcium-dependent cell-cell adhesion system regulates inner cell mass formation and cell surface polarization in early mouse development. Cell 35, 631-638. doi:10.1016/0092-8674(83)90095-8 Smyth, N., Vatansever, H.S., Murray, P., Meyer, M., Frie, C., Paulsson, M., Edgar, D., 1999. Absence of Basement Membranes after Targeting the LAMC1Gene Results in Embryonic Lethality Due to Failure of Endoderm Differentiation. J Cell Biol 144, 151160. doi:10.1083/jcb.144.1.151

Solter, D., Knowles, B.B., 1975. Immunosurgery of mouse blastocyst. Proceedings of the National Academy of Sciences 72, 5099-5102. doi:10.1073/pnas.72.12.5099 Sonnenberg, A., Janssen, H., Hogervorst, F., Calafat, J., Hilgers, J., 1987. A complex of platelet glycoproteins Ic and Ila identified by a rat monoclonal antibody. J. Biol. Chem. 262, 10376-10383.

Steinberg, M.S., Poole, T.J., 1981. Strategies for specifying form and pattern: adhesionguided multicellular assembly. Philosophical Transactions of the Royal Society B:

Biological Sciences 295, 451-460. doi:10.1098/rstb.1981.0153

Stephenson, R.O., Yamanaka, Y., Rossant, J., 2010. Disorganized epithelial polarity and excess trophectoderm cell fate in preimplantation embryos lacking E-cadherin.

Development 137, 3383-3391. doi:10.1242/dev.050195

Streuli, C.H., Schmidhauser, C., Bailey, N., Yurchenco, P., Skubitz, A.P., Roskelley, C., Bissell, M.J., 1995. Laminin mediates tissue-specific gene expression in mammary epithelia. J Cell Biol 129, 591-603. doi:10.1083/jcb.129.3.591

Strnad, P., Gunther, S., Reichmann, J., Krzic, U., Balazs, B., de Medeiros, G., Norlin, N., Hiiragi, T., Hufnagel, L., Ellenberg, J., 2016. Inverted light-sheet microscope for 
imaging mouse pre-implantation development. Nat Meth 13, 139-142.

doi:10.1038/nmeth.3690

Sutherland, A.E., Calarco, P.G., Damsky, C.H., 1993. Developmental regulation of integrin expression at the time of implantation in the mouse embryo. Development 119, 1175-1186.

Takahashi, K., Yamanaka, S., 2006. Induction of pluripotent stem cells from mouse embryonic and adult fibroblast cultures by defined factors. Cell 126, 663-676. doi:10.1016/j.cell.2006.07.024

Takizawa, M., Arimori, T., Taniguchi, Y., Kitago, Y., Yamashita, E., Takagi, J., Sekiguchi, K., 2017. Mechanistic basis for the recognition of laminin-511 by $\alpha 6 \beta 1$ integrin. Sci Adv 3, e1701497. doi:10.1126/sciadv.1701497

Tarkowski, A.K., 1959. Experiments on the Development of Isolated Blastomeres of Mouse Eggs. Nature 184, 1286-1287. doi:10.1038/1841286a0

Tarkowski, A.K., Wróblewska, J., 1967. Development of blastomeres of mouse eggs isolated at the 4- and 8-cell stage. J Embryol Exp Morphol 18, 155-180.

Timpl, R., Rohde, H., Robey, P.G., Rennard, S.I., Foidart, J.M., Martin, G.R., 1979.

Laminin--a glycoprotein from basement membranes. J. Biol. Chem. 254, 9933-9937.

Vinot, S., Le, T., Ohno, S., Pawson, T., Maro, B., Louvet-Vallée, S., 2005. Asymmetric distribution of PAR proteins in the mouse embryo begins at the 8-cell stage during compaction. Developmental Biology 282, 307-319. doi:10.1016/j.ydbio.2005.03.001

Walma, D.A.C., Yamada, K.M., 2020. The extracellular matrix in development.

Development 147. doi:10.1242/dev.175596

Watt, F.M., Huck, W.T.S., 2013. Role of the extracellular matrix in regulating stem cell fate. Nature Reviews Molecular Cell Biology 14, 467-473. doi:10.1038/nrm3620

Wicklow, E., Blij, S., Frum, T., Hirate, Y., Lang, R.A., Sasaki, H., Ralston, A., 2014. HIPPO pathway members restrict SOX2 to the inner cell mass where it promotes ICM fates in the mouse blastocyst. PLoS Genet. 10, e1004618.

doi:10.1371/journal.pgen.1004618

Wigger, M., Kisielewska, K., Filimonow, K., Plusa, B., Maleszewski, M., Suwińska, A., 2017. Plasticity of the inner cell mass in mouse blastocyst is restricted by the activity of FGF/MAPK pathway. Nature Publishing Group 7, 15136. doi:10.1038/s41598017-15427-0

Williamson, R.A., Henry, M.D., Daniels, K.J., Hrstka, R.F., Lee, J.C., Sunada, Y., Ibraghimov-Beskrovnaya, O., Campbell, K.P., 1997. Dystroglycan is essential for 
early embryonic development: disruption of Reichert's membrane in Dag1-null mice. Hum. Mol. Genet. 6, 831-841. doi:10.1093/hmg/6.6.831

Wolpert, L., 1969. Positional information and the spatial pattern of cellular differentiation.

J. Theor. Biol. 25, 1-47. doi:10.1016/s0022-5193(69)80016-0

Yamada, M., Sekiguchi, K., 2015. Molecular Basis of Laminin-Integrin Interactions. Curr Top Membr 76, 197-229. doi:10.1016/bs.ctm.2015.07.002

Ziomek, C.A., Johnson, M.H., 1980. Cell surface interaction induces polarization of mouse 8-cell blastomeres at compaction. Cell 21, 935-942. doi:10.1016/00928674(80)90457-2 
Figure 1

A

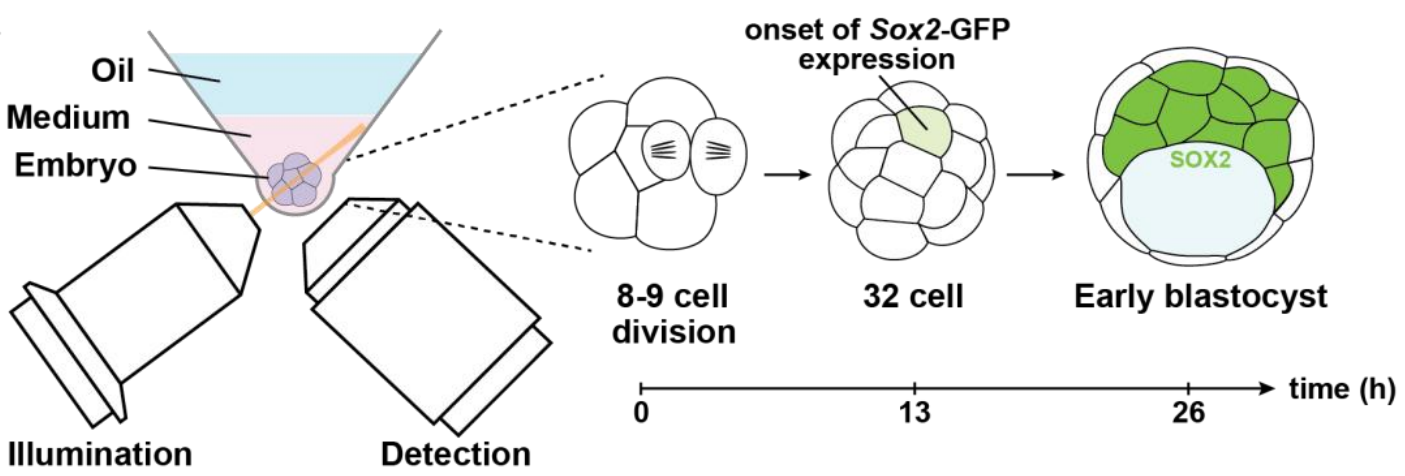

B

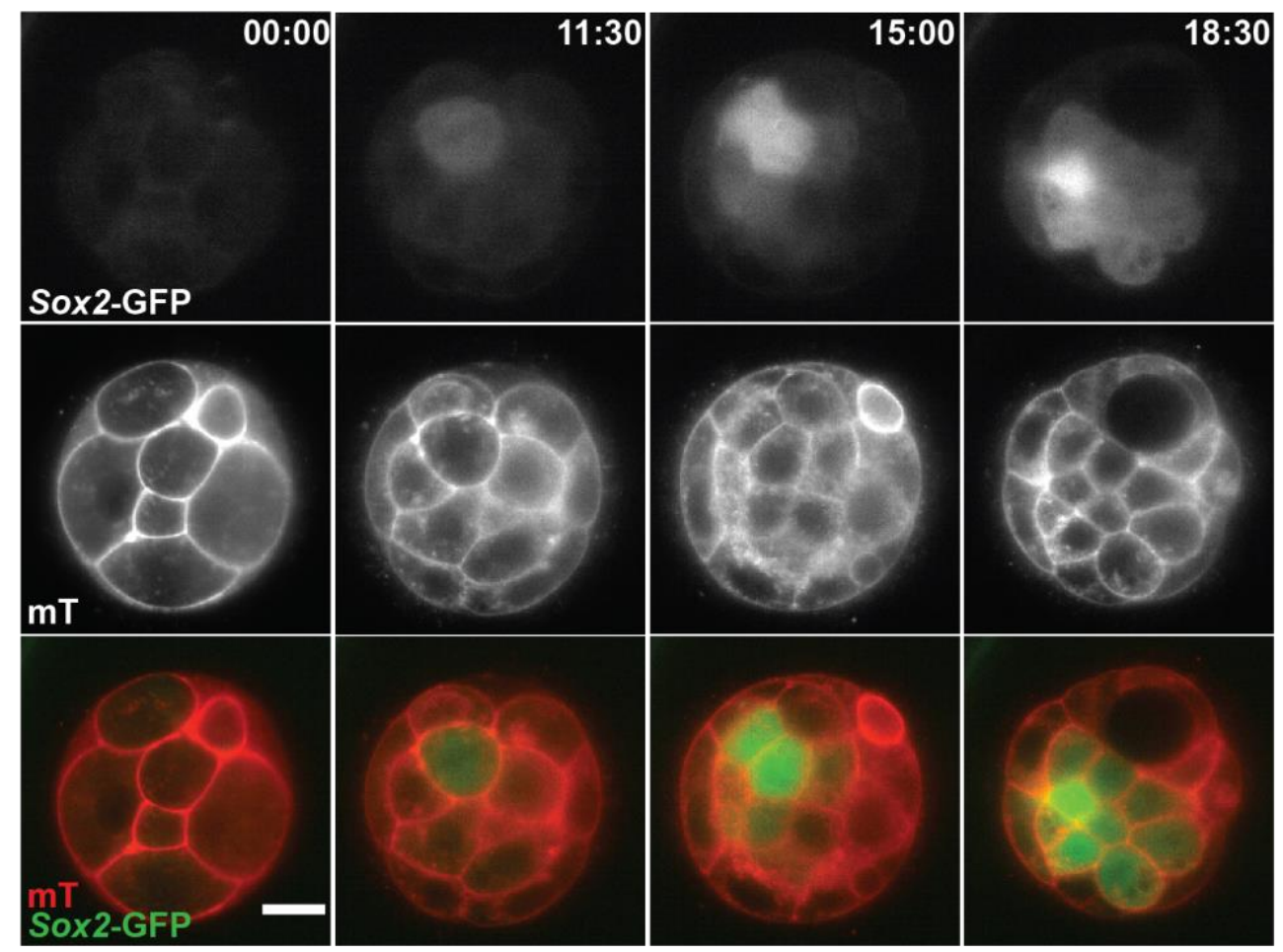

C

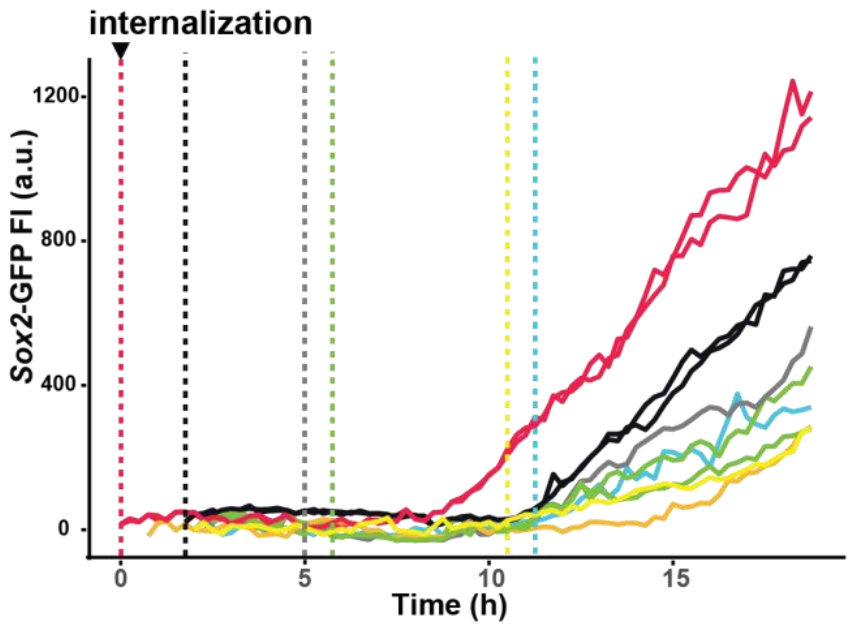

D

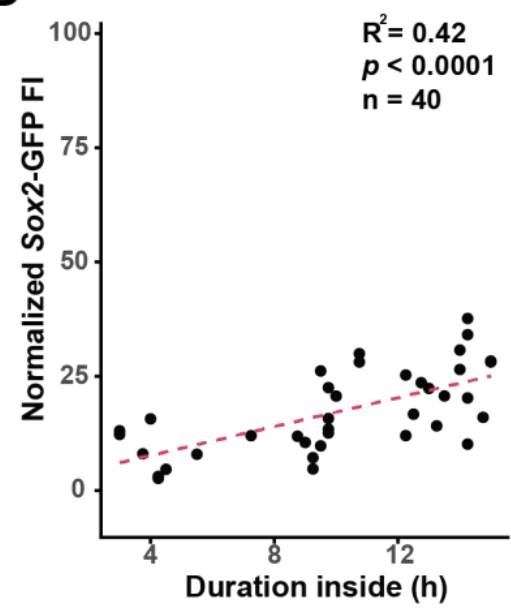


bioRxiv preprint doi: https://doi.org/10.1101/2021.07.05.450860; this version posted July 5, 2021. The copyright holder for this preprint

(which was not certified by peer review) is the author/funder, who has granted bioRxiv a license to display the preprint in perpetuity. It is made available under aCC-BY-NC-ND 4.0 International license.

Figure 2

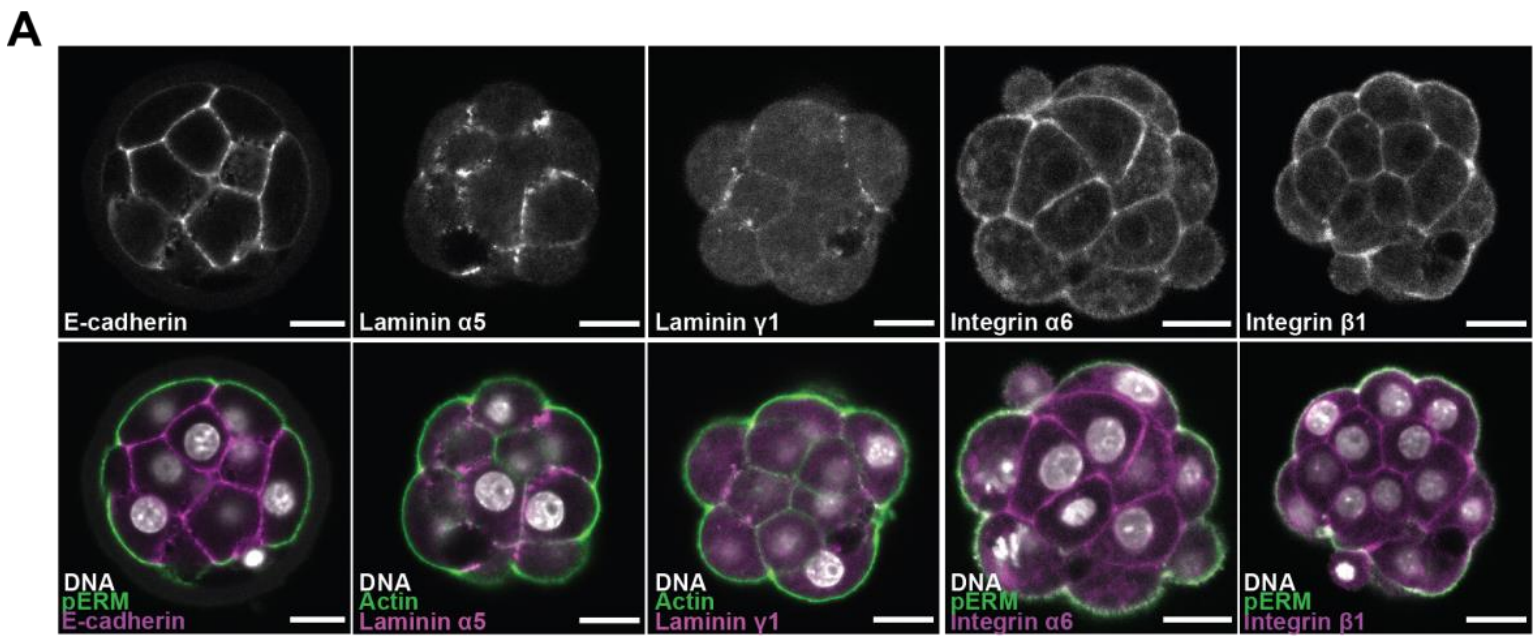

B

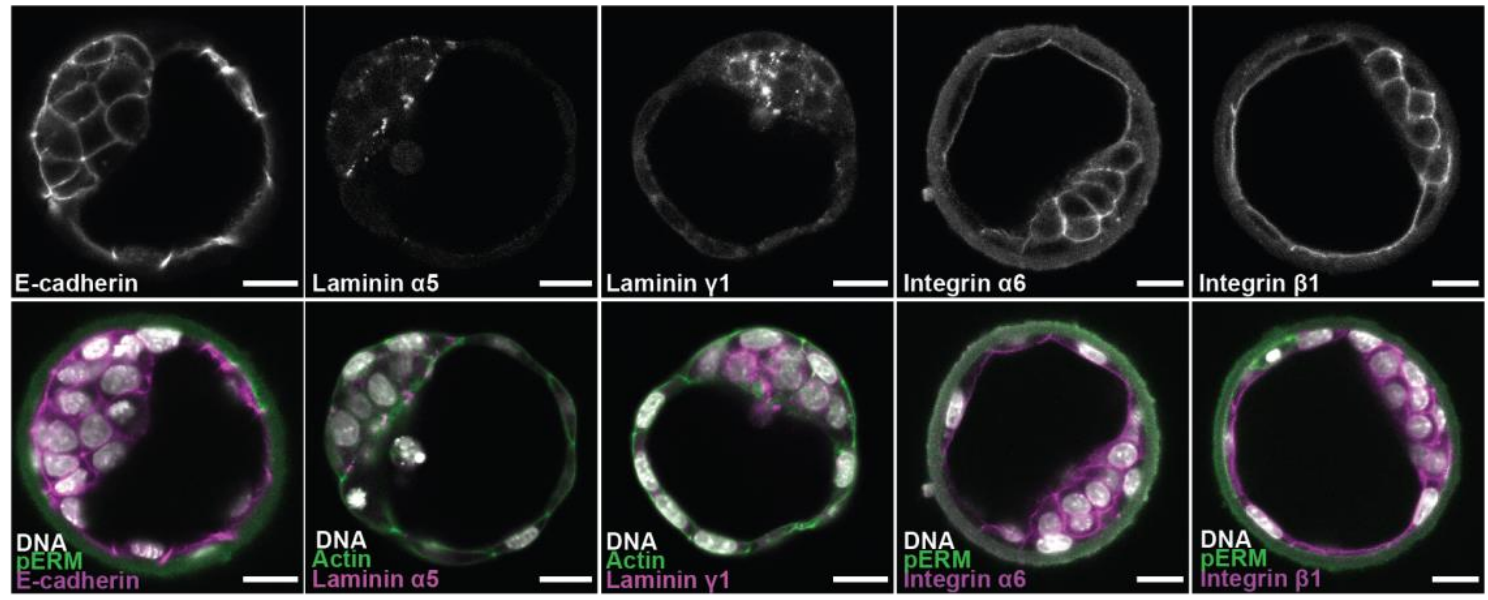

C

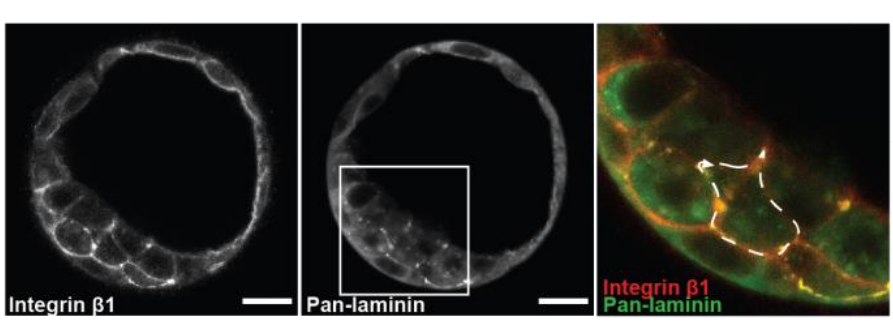

D

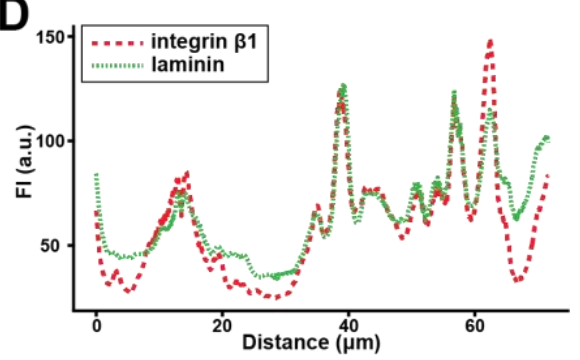


bioRxiv preprint doi: https://doi.org/10.1101/2021.07.05.450860; this version posted July 5, 2021. The copyright holder for this preprint (which was not certified by peer review) is the author/funder, who has granted bioRxiv a license to display the preprint in perpetuity. It is made available under aCC-BY-NC-ND 4.0 International license.

Figure 3

A

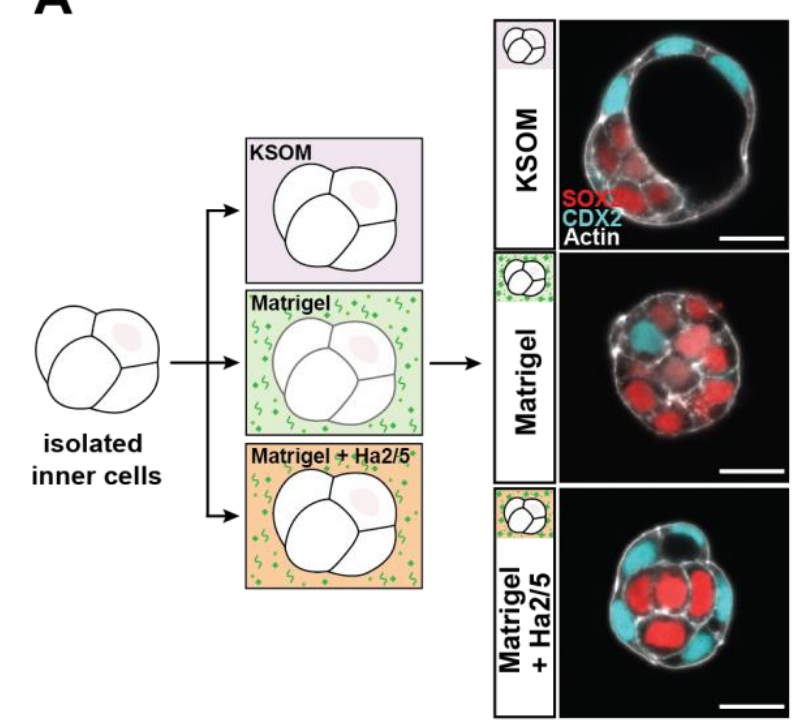

C

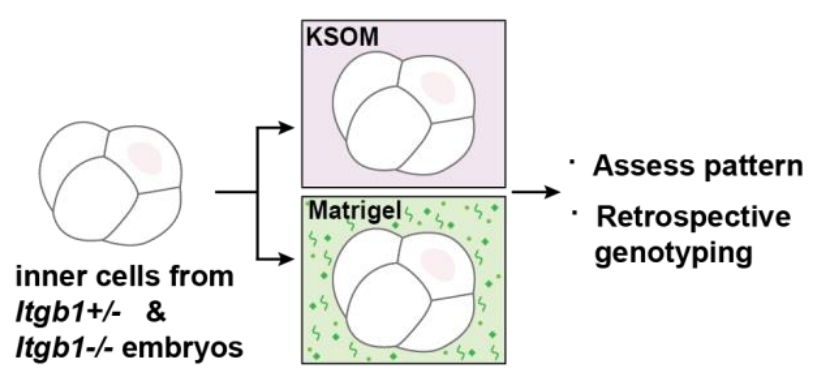

B
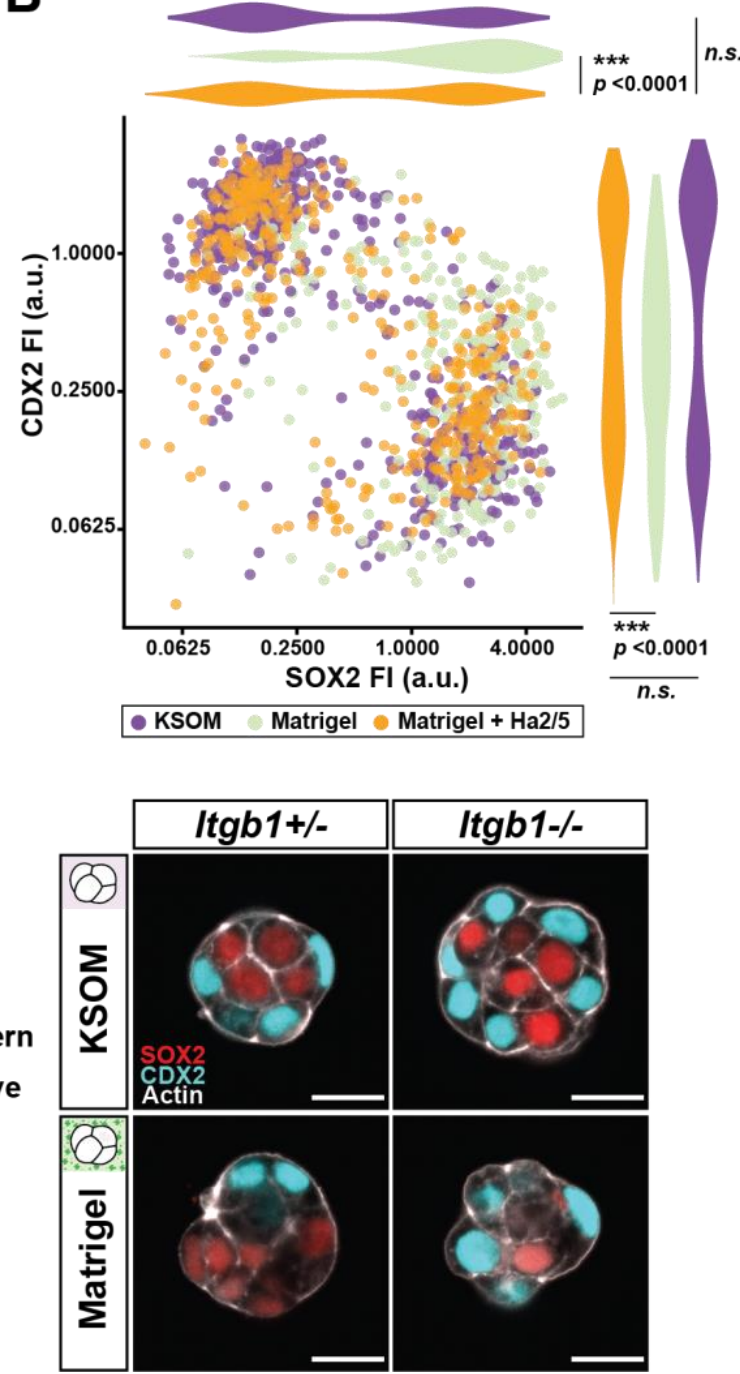
Figure 4

A

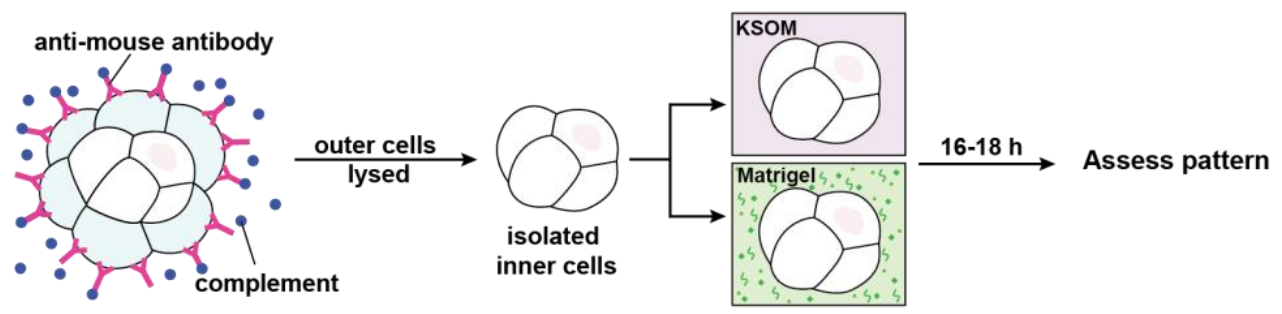

\section{E2.5 - 2.75}

B

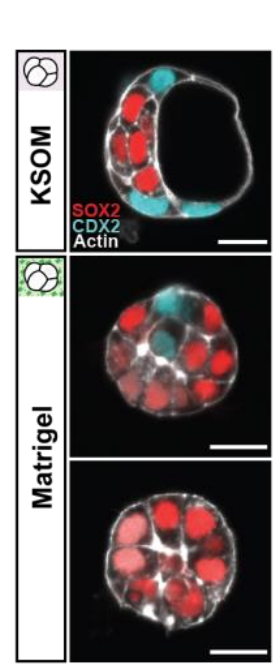

E

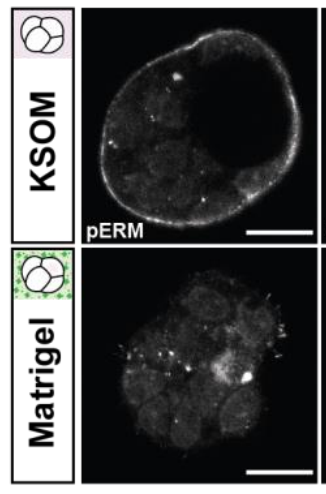

C

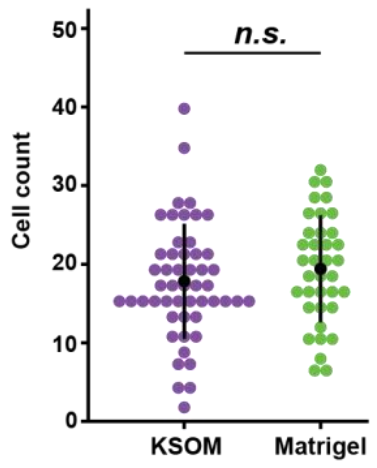

D

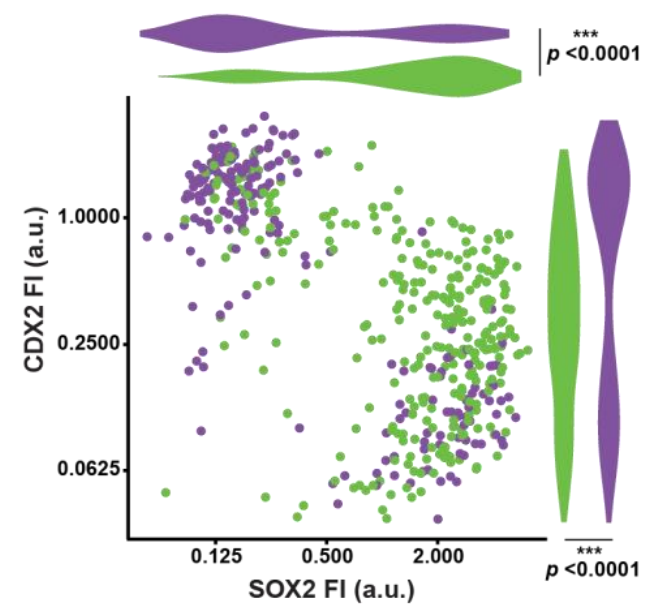

F
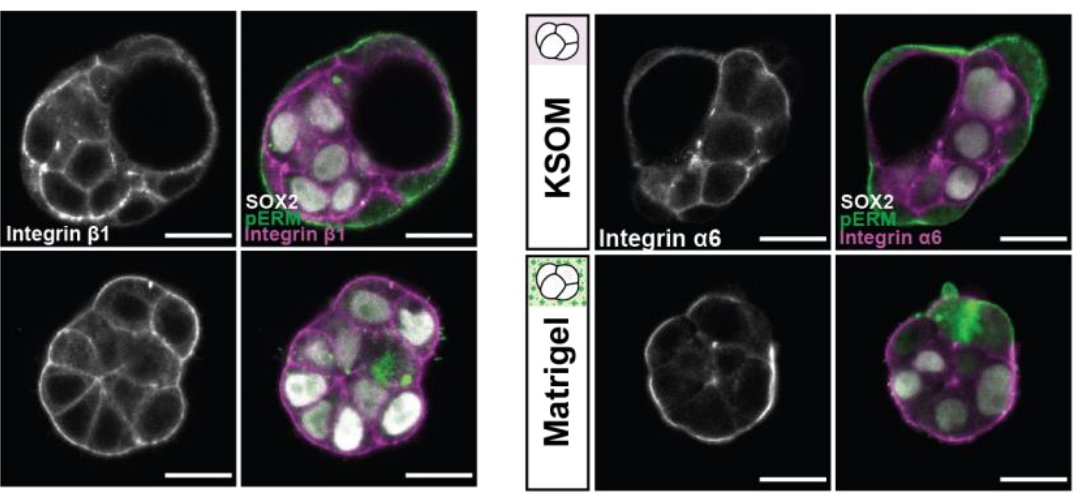

G

H
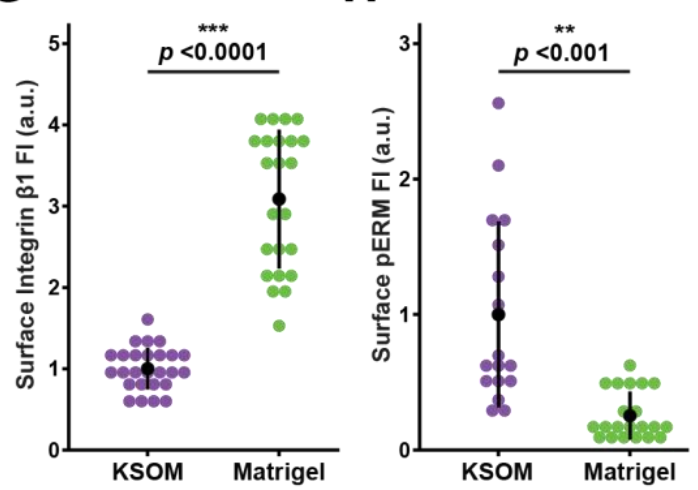

I
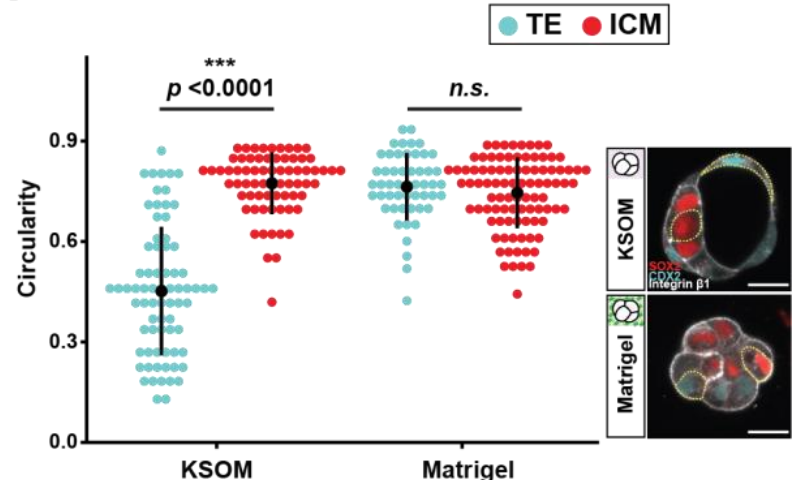
Figure 5

A

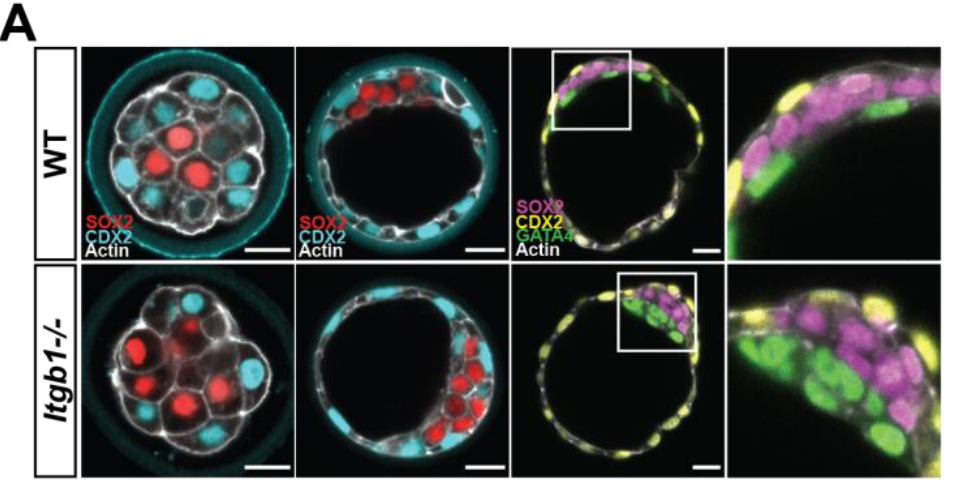

C

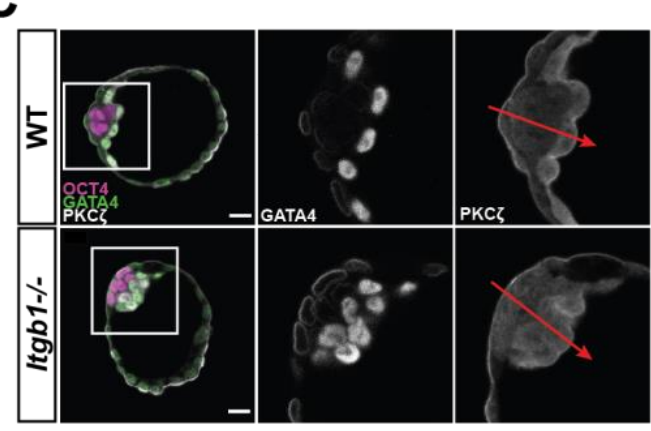

B

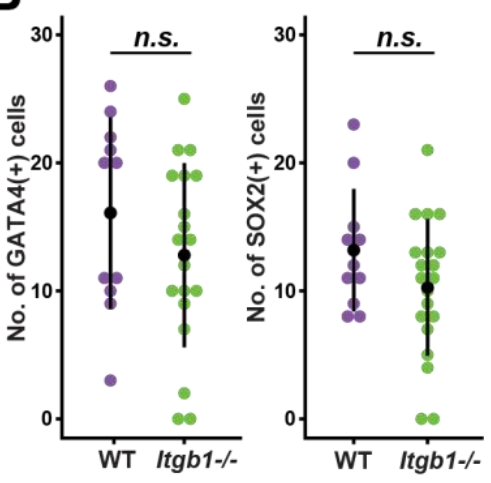

E

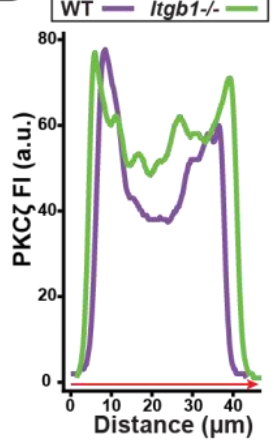

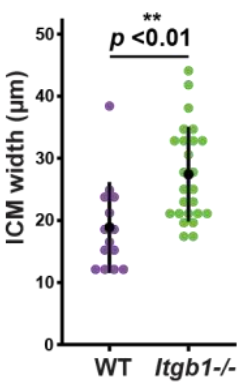

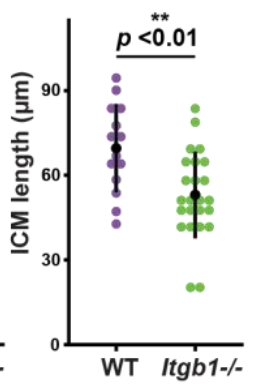


Figure 6

A

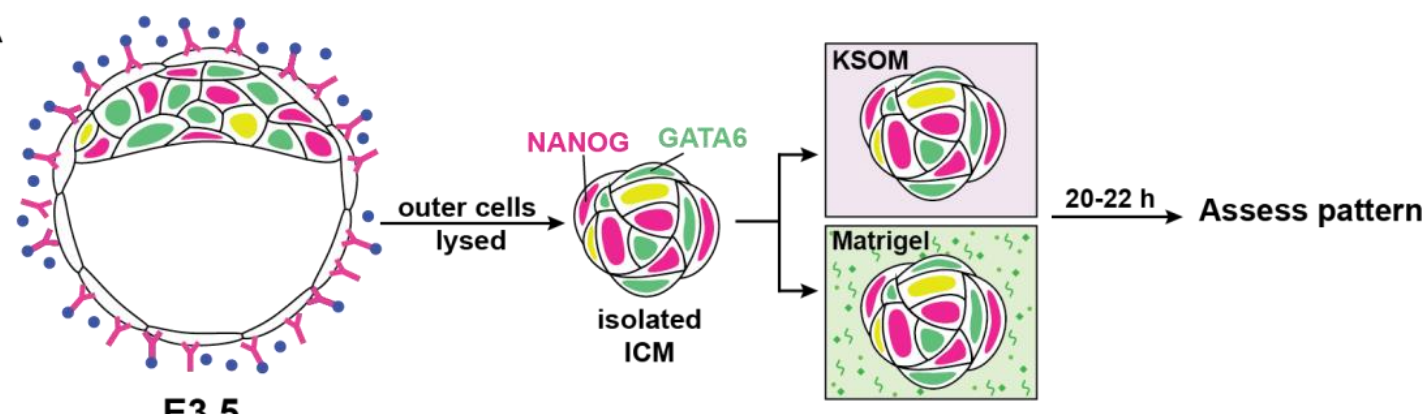

E3.5

B

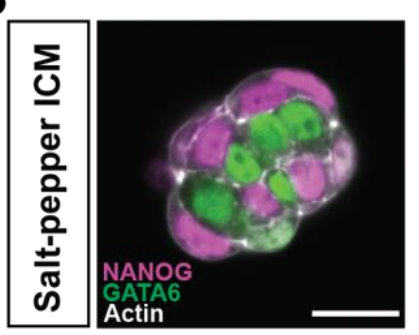

D

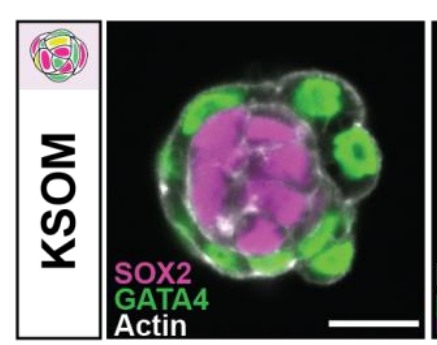

$\mathbf{F}$
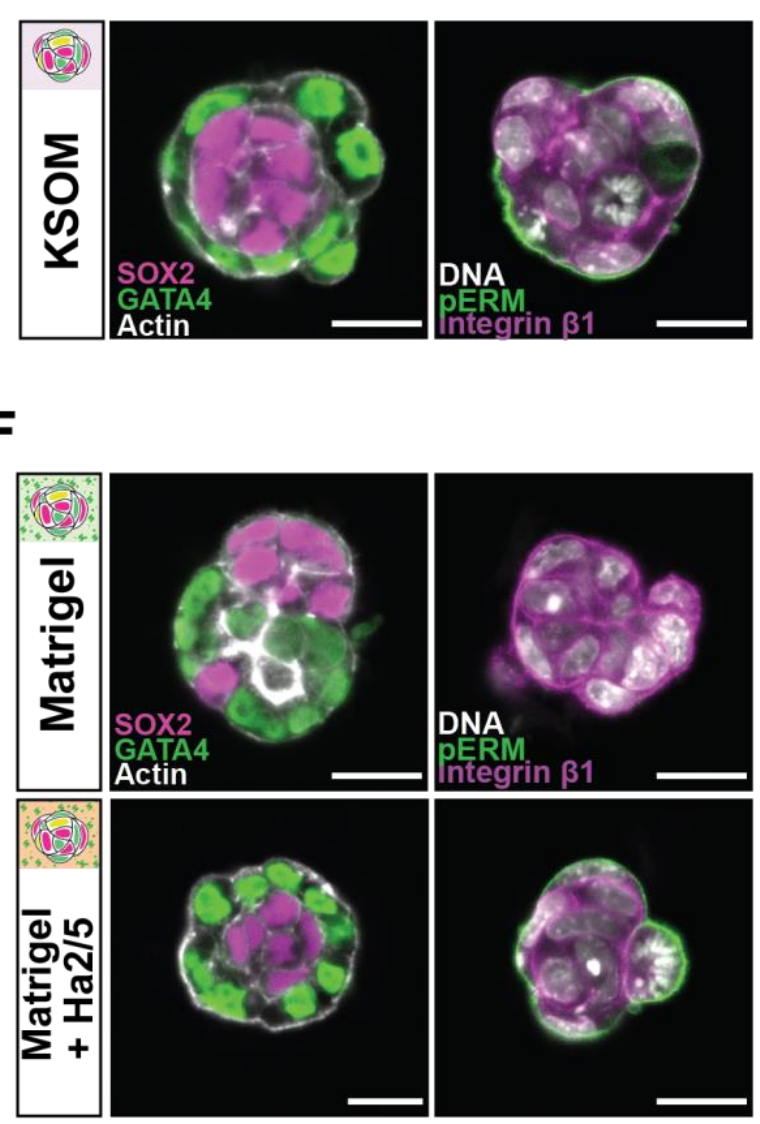

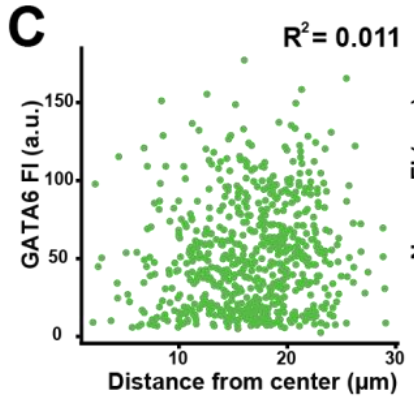

E

E
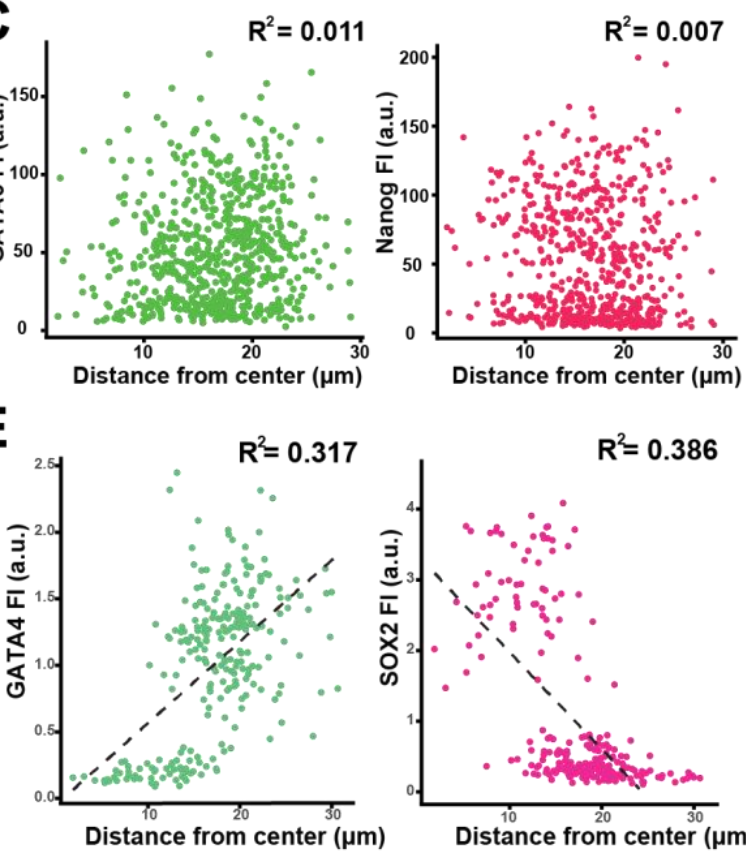

G

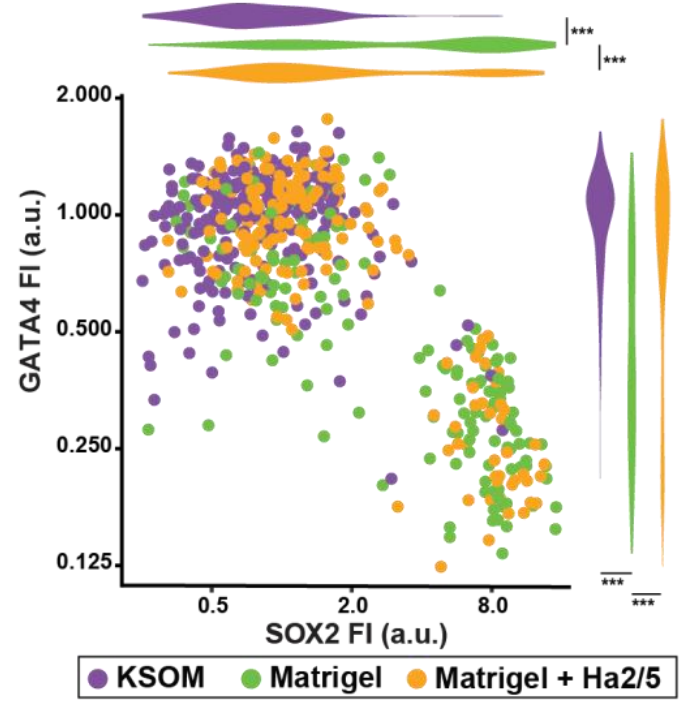


bioRxiv preprint doi: https://doi.org/10.1101/2021.07.05.450860; this version posted July 5, 2021. The copyright holder for this preprint (which was not certified by peer review) is the author/funder, who has granted bioRxiv a license to display the preprint in perpetuity. It is made available under aCC-BY-NC-ND 4.0 International license.

Figure 7

A

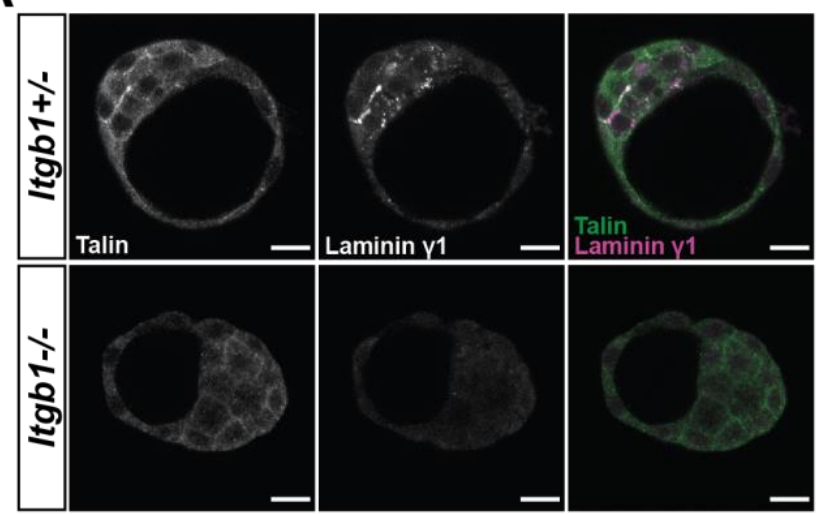

B

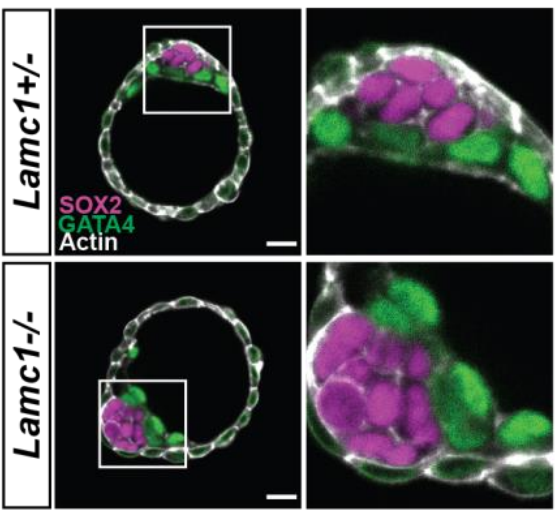

C

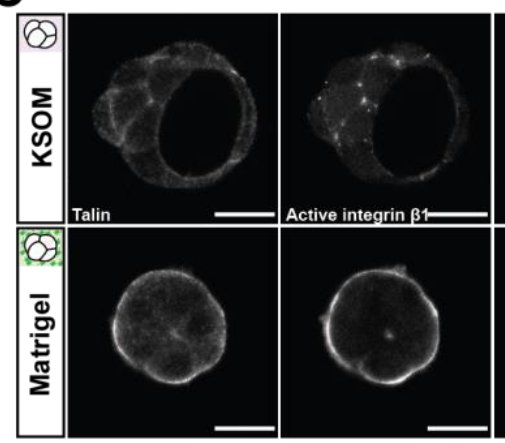

D

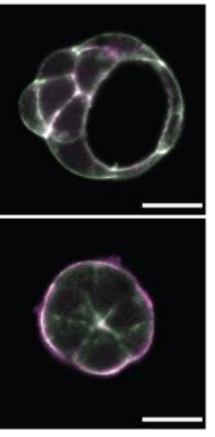

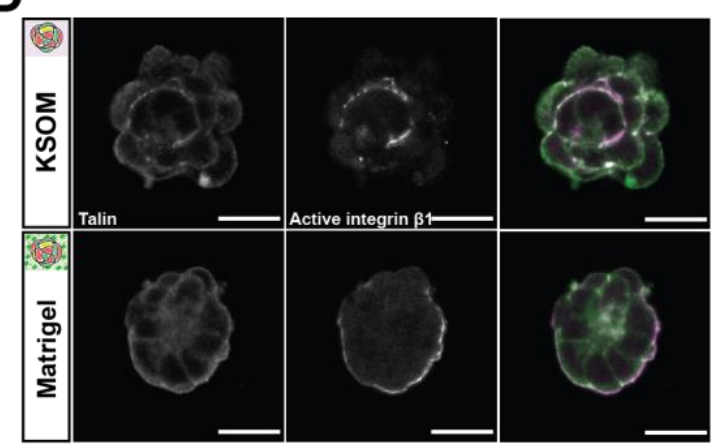

$\mathbf{E}$
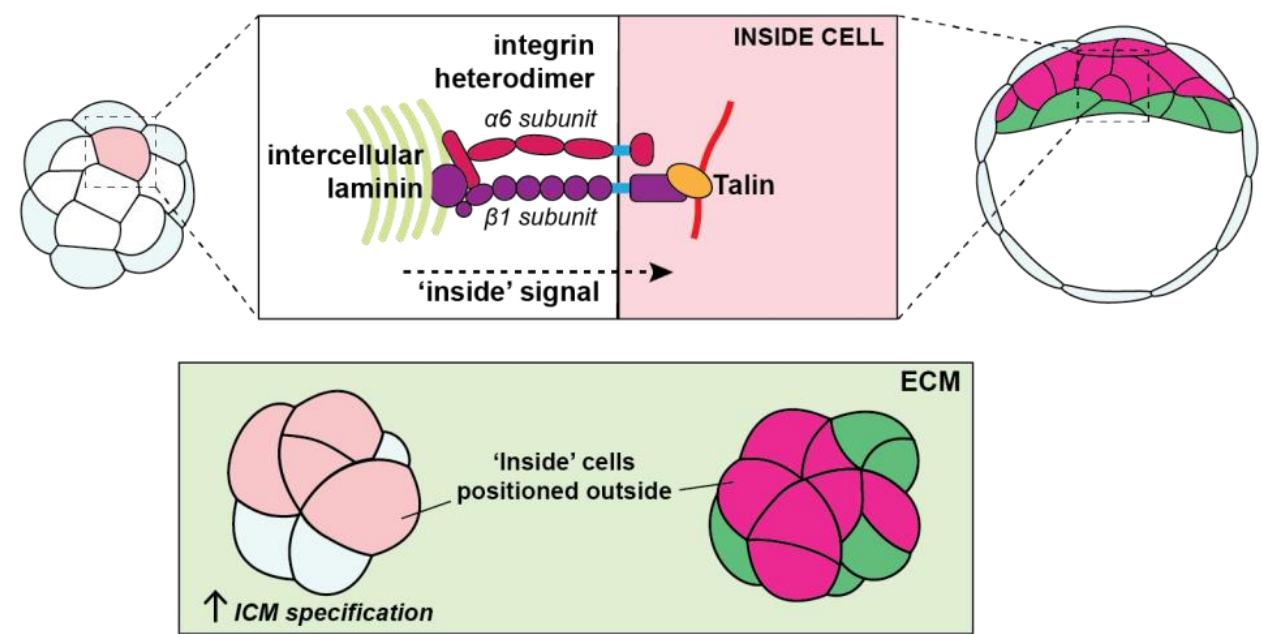
bioRxiv preprint doi: https://doi.org/10.1101/2021.07.05.450860; this version posted July 5, 2021. The copyright holder for this preprint (which was not certified by peer review) is the author/funder, who has granted bioRxiv a license to display the preprint in perpetuity. It is made available under aCC-BY-NC-ND 4.0 International license.

Figure S1

A

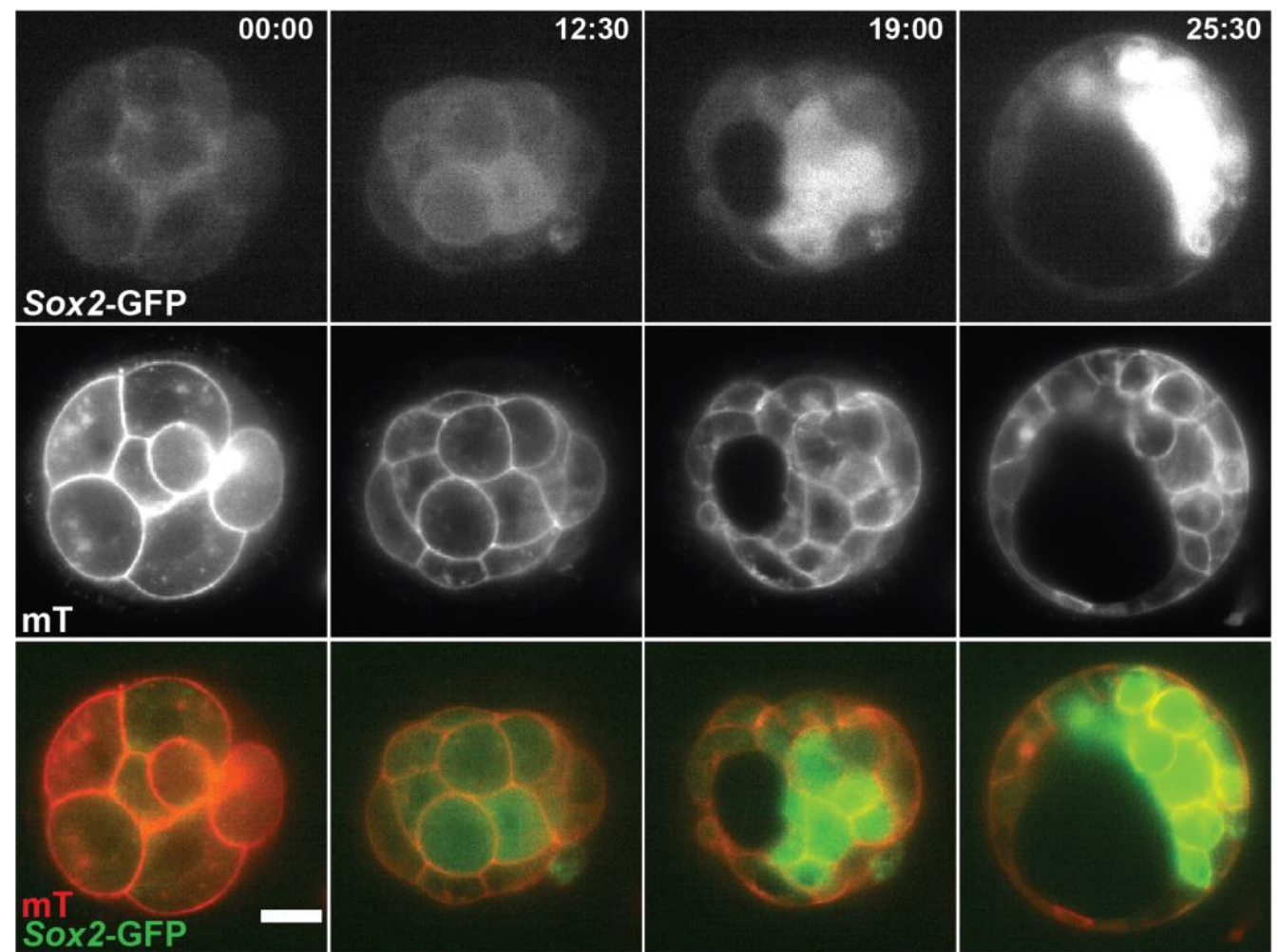

B
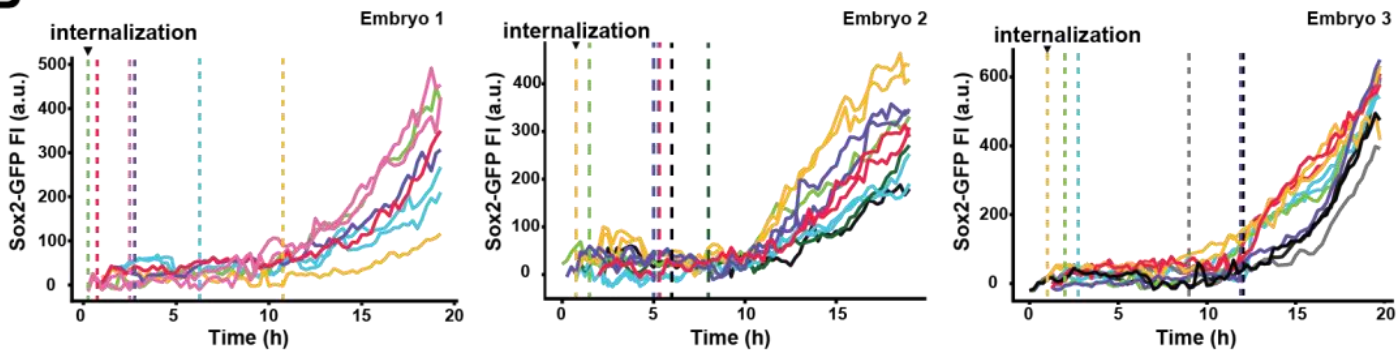
bioRxiv preprint doi: https://doi.org/10.1101/2021.07.05.450860; this version posted July 5, 2021. The copyright holder for this preprint (which was not certified by peer review) is the author/funder, who has granted bioRxiv a license to display the preprint in perpetuity. It is made available under aCC-BY-NC-ND 4.0 International license.

Figure S2

A

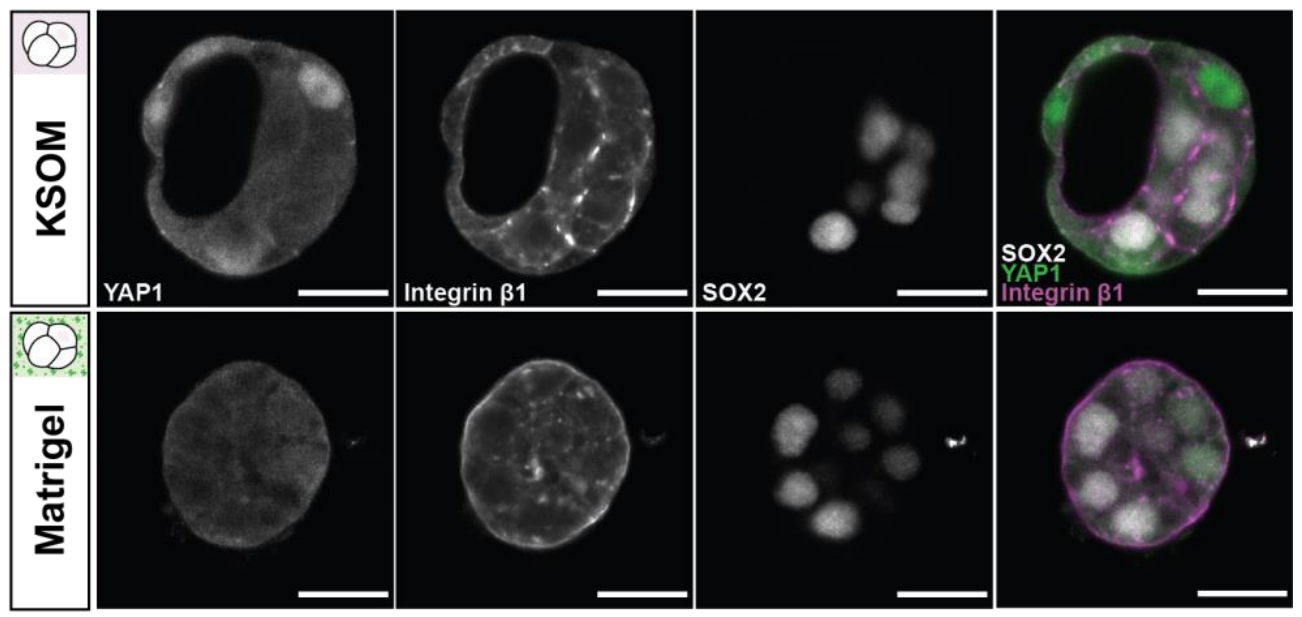

B

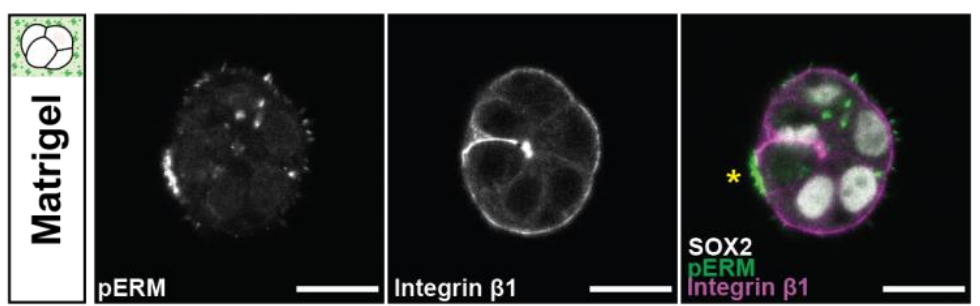

C

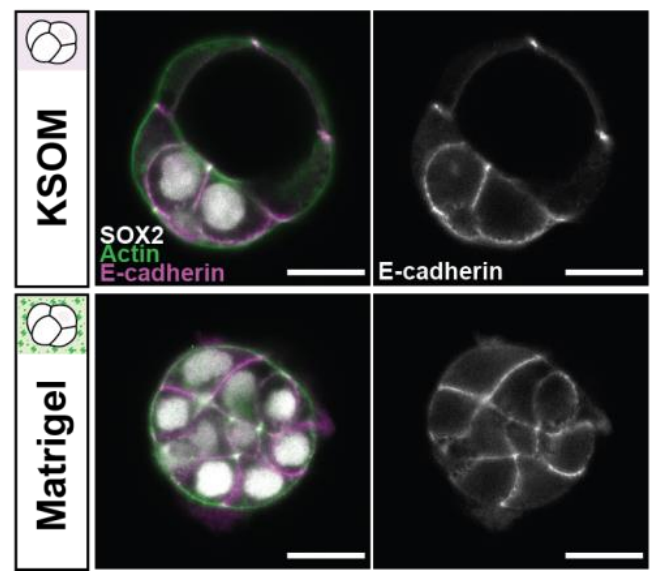


bioRxiv preprint doi: https://doi.org/10.1101/2021.07.05.450860; this version posted July 5, 2021. The copyright holder for this preprint (which was not certified by peer review) is the author/funder, who has granted bioRxiv a license to display the preprint in perpetuity. It is made available under aCC-BY-NC-ND 4.0 International license.

Figure S3

A

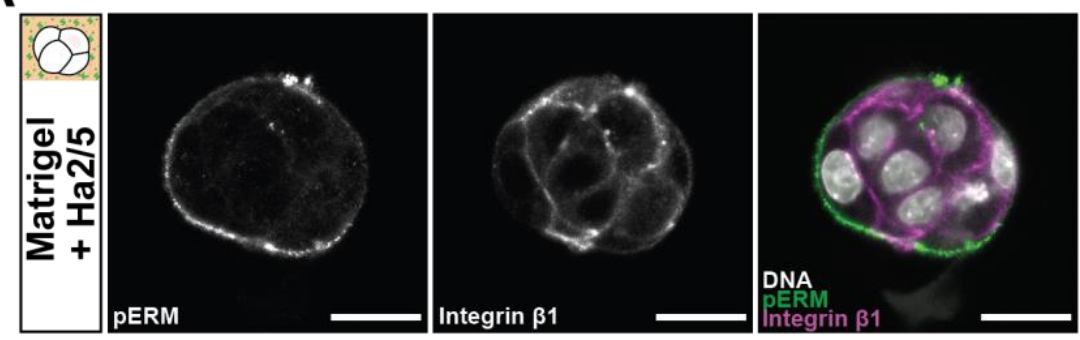

B

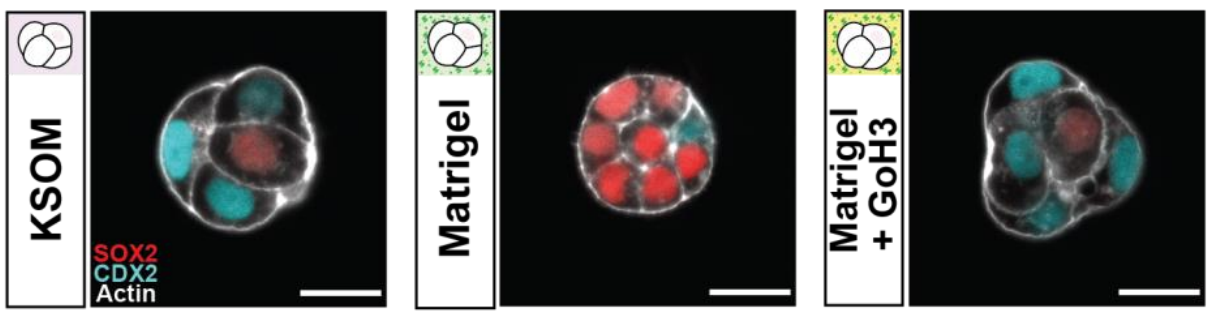

C

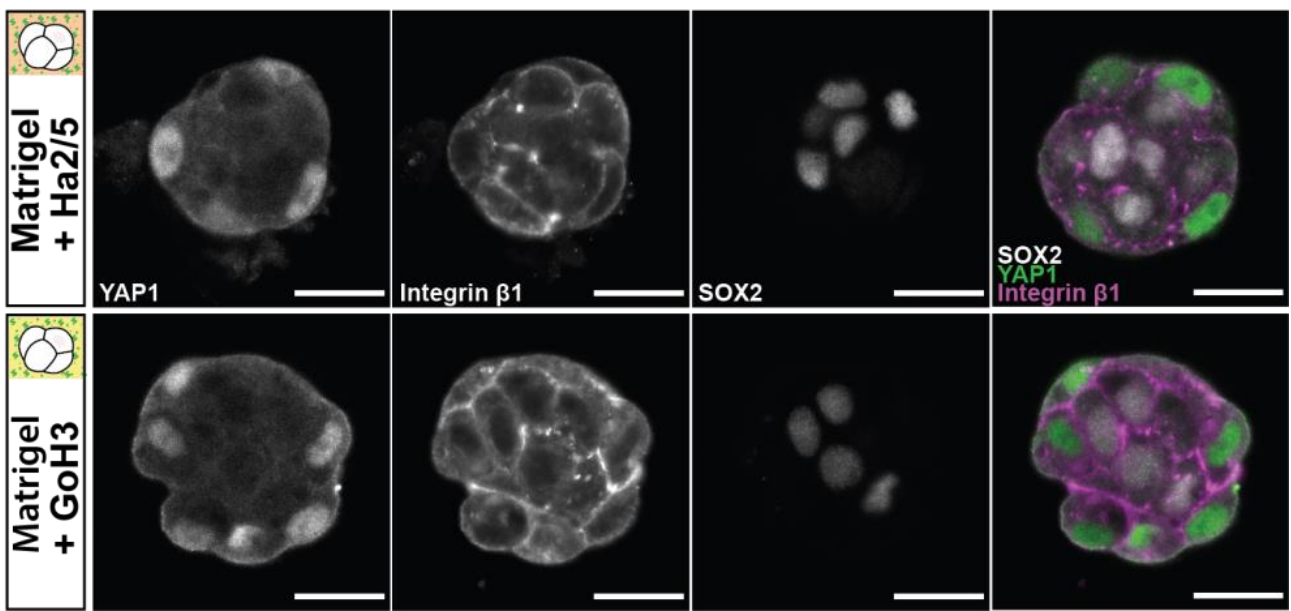

